Atmos. Chem. Phys. Discuss., 11, 4953-5001, 2011

www.atmos-chem-phys-discuss.net/11/4953/2011/

doi:10.5194/acpd-11-4953-2011

(c) Author(s) 2011. CC Attribution 3.0 License.

\title{
The DAURE field campaign: meteorological overview
}

\section{O. Jorba ${ }^{1}$, M. Pandolfi ${ }^{2}$, M. Spada ${ }^{1}$, J. M. Baldasano ${ }^{1,3}$, J. Pey ${ }^{2}$, A. Alastuey ${ }^{2}$,} D. Arnold ${ }^{4,5}$, M. Sicard ${ }^{6,7}$, B. Artiñano ${ }^{8}$, M. A. Revuelta ${ }^{8}$, and X. Querol $^{2}$

${ }^{1}$ Earth Sciences Department, Barcelona Supercomputing Center-Centro Nacional de Supercomputacion, Barcelona, Spain

${ }^{2}$ Institute of Environmental Assessment and Water Research, National Research Council, Barcelona, Spain

${ }^{3}$ Environmental Modeling Laboratory, Technical University of Catalonia, Barcelona, Spain

${ }^{4}$ Institute of Meteorology, University of Natural Resources and Life Sciences, Vienna, Austria

${ }^{5}$ Institute of Energy Technologies, Technical University of Catalonia, Barcelona, Spain

${ }^{6}$ Remote Sensing Lab., Signal Theory and Communications Department, Technical University of Catalonia, Barcelona, Spain

${ }^{7}$ Institute for Space Studies of Catalonia, Barcelona, Spain
DAURE campaign meteorological overview

O. Jorba et al.

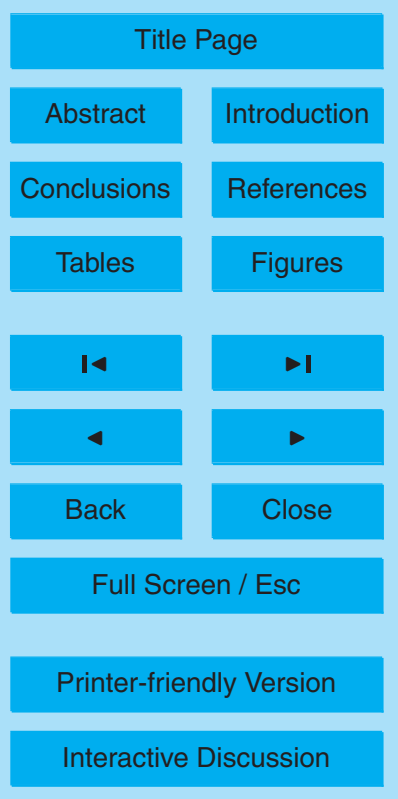


${ }^{8}$ Research Centre on Energy, Environment and Technology CIEMAT, Madrid, Spain

Received: 20 December 2010 - Accepted: 27 January 2011 - Published: 9 February 2011

Correspondence to: O. Jorba (oriol.jorba@bsc.es)

Published by Copernicus Publications on behalf of the European Geosciences Union.

\section{ACPD}

11, 4953-5001, 2011

DAURE campaign meteorological overview

O. Jorba et al.

Title Page

Abstract

Introduction

Conclusions

References

Tables

Figures

14

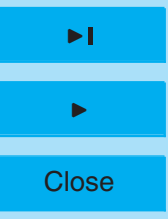

Back

Full Screen / Esc

Printer-friendly Version

Interactive Discussion 


\section{Abstract}

From end of February until March 2009 and July 2009 the experimental campaign named DAURE took place in northeastern Spain in both an urban and rural sites (Barcelona city and Montseny Natural Park) with the main objective of studying the 5 formation and transport processes of particulate matter in the region. Several groups collaborated in an extensive measurement campaign with aerosol monitoring, meteorological measurements, atmospheric vertical structure retrievals from LIDAR and supported by numerical simulations of the meteorological and air quality conditions over the region. In this article, we present a description of the main meteorological conditions that affected the Barcelona geographical area during the campaign. The main synoptic conditions are identified and discussed by means of meteorological observations and numerical weather prediction models. Furthermore, a detailed analysis of the local meteorological conditions during the campaign is also presented. The characteristic surface wind field and the vertical structure of the main flows affecting Barcelona

15 and the Montseny rural site are discussed using high-resolution mesoscale meteorological simulations, vertical profiles of LIDAR measurements, radiosoundings, and analysis of backward dispersion simulations with a Lagrangian model. The analysis permits the identification of three main meteorological regimes for the winter campaign (February and March 2009): a first regime dominated by high-pressure conditions over Barcelona and western Mediterranean Basin, high insolation, and the development of thermally-driven wind flows. A second regime is characterized by a strong northwestern advection that produced a cleansing action over the atmosphere. And a third identified regime is dominated by strong stagnant conditions produced by thermal inversions that decouple the low troposphere of plain and coastal areas from mountainous terrains. On the other hand, the main meteorological regimes identified for the summer campaign (July 2009) are: a typical summer recirculation pattern, with low pressure gradients over the western Mediterranean basin, high insolation and development of mesoscale features, a second pattern characterized by the advection of southern air

DAURE campaign

meteorological overview

O. Jorba et al.

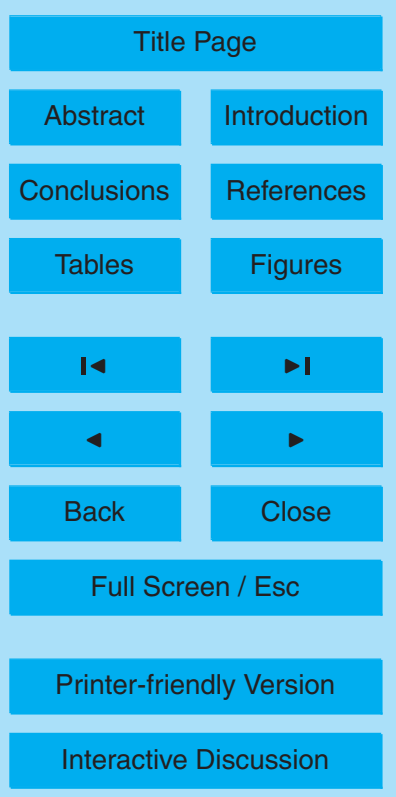

Interactive Discussion 
masses enriched with mineral dust from North Africa, and a third zonal advective scenario associated with frontal systems that inhibits the mesoscale circulations and leads to some precipitating events over northeastern Spain. Finally, a classification of the main dispersion patterns deduced from backward Lagrangian simulations is presented 5 and discussed. The results help identify the main flow patterns that lead to the formation and accumulation of particulate matter within the boundary layer, and may produce high pollutant concentrations at Montseny or Barcelona sites. During the DAURE winter and summer campaigns, typical meteorological conditions that lead to air pollution episodes of particulate matter within the Western Mediterranean Basin were observed.

\section{Introduction}

Several studies have outlined the particular behavior of tropospheric aerosol dynamics and physics in northeastern Spain (Querol et al., 1998a,b, 2001b,a; Viana et al., 2005, 2006; Pey et al., 2008; Perez et al., 2008b,a). The understanding of the origin, transport and reaction processes of tropospheric aerosols is a major concern considering the impacts on health (Pope et al., 2009), the Earth's climate (IPCC, 2007), visibility, continental and maritime ecosystems, and building materials. In this context, a field campaign was designed and conducted in northeastern Spain to better understand the main processes that contribute to the increased particulate matter levels observed in urban and rural environment in the Western Mediterranean Basin (WMB) (e.g., Viana et al., 2005, 2006). The campaign "Determination of the sources of atmospheric Aerosols in Urban and Rural Environments in Spain" (DAURE; Pandolfi et al., 2011) has as its main objective the characterization of the sources of fine aerosols in the Barcelona region, with particular attention to carbonaceous aerosols. The campaign is also part of the EMEP Coordinated Winter Campaign program. DAURE took
ACPD

11, 4953-5001, 2011

DAURE campaign

meteorological overview

O. Jorba et al.

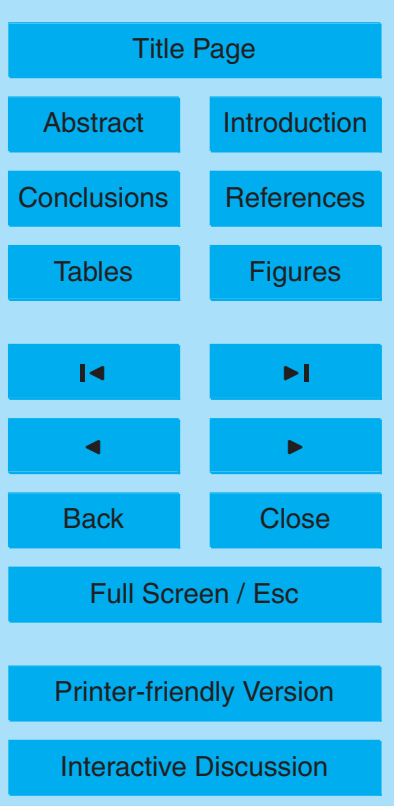


Several groups contributed to the field measurements and modelling activities: Spanish National Research Council (CSIC, Spain), University of Colorado (Boulder, USA), Centre for Ecology and Hydrology (Scotland, UK), Paul Scherrer Institut (Switzerland), Barcelona Supercomputing Center (BSC, Spain), Centre for Ecological Re5 search and Forestry Applications (CREAF, Spain), Research Centre on Energy, Environment and Technology (CIEMAT, Spain), Technical University of Catalonia (UPC, Spain), and University of Barcelona (UB, Spain). The field measurements were obtained at two sites in NE Spain, an urban site in Barcelona city (BCN), and a rural background site at the Montseny Natural Park (MSY). The MSY station is of high rele10 vance due to its geographical location between the boundary of the Western Mediterranean Basin (WMB) and the Iberian Peninsula environments. Moreover, it is also part of the European Supersites for Atmospheric Aerosol Research network (EUSAAR, http://www.eusaar.net/). Both sites lie within the Barcelona geographical area (Fig. 1).

The Barcelona geographical area has Mediterranean climate conditions and may 15 undergo severe weather events. The area is affected by convergence of air masses with different characteristics: the cold air coming down from medium and high latitudes, and the warm air coming up from tropical and subtropical latitudes. The former mainly dominates during the winter months, while the latter, characterized by anticyclones in the middle and upper layers of the troposphere, is predominantly observed during the summer. For this reason, the summer season is dry while the rest of the year is moderately humid (Clavero et al., 1997). The mountain ranges surrounding the Mediterranean Sea act as a sharp climate barrier protecting the Mediterranean basin from more extreme continental weather conditions. Thus, the coastal and pre-coastal zones of the WMB, the Barcelona geographical area included, present a winter regime characterized by low precipitation, a warm and dry summer and a rainy autumn. The major orographic features that influence the flows to BCN are the Pyrenees Mountains and the Ebro Valley, acting as a natural barrier of the flows and producing important orographic forcings into the low troposphere. In a local scale, BCN is dominated by the coastal depression, coastal mountain range, pre-coastal depression and pre-coastal

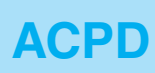

11, 4953-5001, 2011

\section{DAURE campaign \\ meteorological overview}

O. Jorba et al.

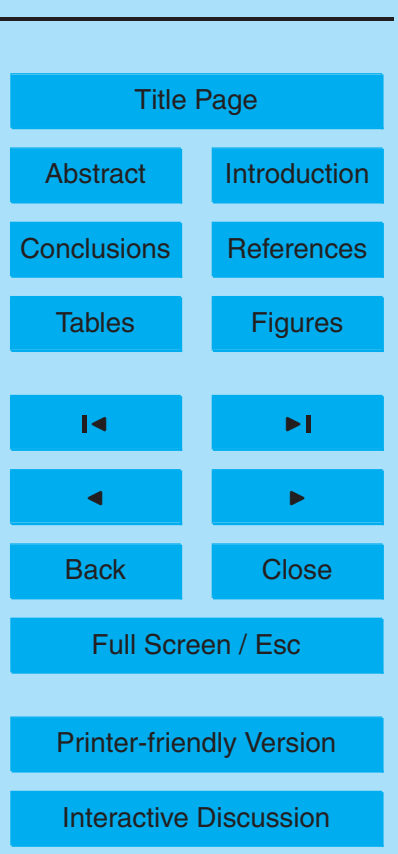

Interactive Discussion 
mountain range where the MSY site is located (Fig. 1). There are two main river valleys perpendicular to the coast limiting the $\mathrm{BCN}$ area. These valleys contain highways and roads that link the Barcelona urban area and its outlying towns with the cities in the pre-coastal depression. Many industries are located around these urban areas. The 5 development of thermally-driven flows and forced channelizations of synoptic flows have important effects in the dispersion of the pollutants emitted within the area under study.

This paper presents an overview of the meteorological conditions occurring during the DAURE winter and summer campaigns. It is intended to constitute a reference 10 for the meteorological information for further publications associated with analyses of the dynamics of aerosol formation and transport for the DAURE measurements. The main synoptic patterns are identified together with the mesoscale processes that lead to complex dispersion pathways within the area under study. Meteorological observations, LIDAR profiles, meteorological analysis, high-resolution mesoscale meteorological forecasts, and dispersion simulations are used to present the description of the meteorological conditions for the campaign. Overall, the most typical meteorological situations associated to pollution episodes of particulate matter within the WMB were observed during DAURE. The following section briefly describes the DAURE campaign. Section 3 summarizes the winter campaign meteorological conditions, from synoptic to local scales. The meteorological conditions for the summer campaign are described in Sect. 4. Finally, a summary and conclusions are included in Sect. 5.

\section{DAURE campaign description}

\subsection{Measurements}

Measurements and sampling of aerosols during the DAURE campaign were simultaneously conducted at two sites of NE Spain during winter (February and March 2009) and summer (July 2009). The selected measurement sites were the Barcelona urban site

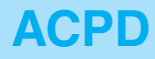

11, 4953-5001, 2011

\section{DAURE campaign \\ meteorological overview}

O. Jorba et al.

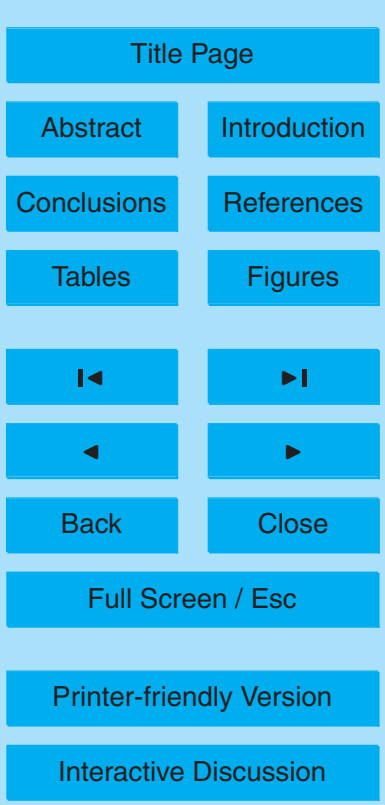


$\left(\mathrm{BCN} ; 41^{\circ} 23^{\prime} 24.01^{\prime \prime} \mathrm{N} 2^{\circ} 06^{\prime} 58.06^{\prime \prime} \mathrm{E}, 80 \mathrm{~m}\right.$ a.s.I.) and the Montseny rural site (MSY; $41^{\circ} 46^{\prime} 45.63^{\prime \prime} \mathrm{N}{ }^{\circ} 21^{\prime} 28.92^{\prime \prime} \mathrm{E}, 720$ ma.s.l.) (Fig. 1). In order to characterize the particulate matter several measurements techniques were applied ranging from state-ofthe-art methods such as ${ }^{14} \mathrm{C}$ (Szidat et al., 2006; Lanz et al., 2007) and HR-ToF-AMS 5 (Jimenez et al., 2003; deCarlo et al., 2006) to classical PM measurements and speciation.

For a further description of the DAURE campaign and the chemical measurement techniques applied, the reader is referred to companion paper from Pandolfi et al. (2011).

10 For the DAURE campaign several meteorological measurements were available. The NE Spain is covered with a dense surface meteorological network operated by the Catalan Meteorological Service. A total of 166 stations measure air temperature and relative humidity at $2 \mathrm{~m}$, surface pressure, wind speed and direction at $10 \mathrm{~m}$, precipitation and global solar radiation. All measurements have a $30 \mathrm{~min}$ or $1 \mathrm{~h}$ temporal 15 resolution. Figure 1 shows the distribution of the stations located near the area of interest. To complement the available meteorological observations, the CSIC group operated a meteorological station at the MSY and BCN sites with a 10 min temporal resolution.

Additionally, radiosoundings were launched twice per day over Barcelona city near 20 the BCN site. The soundings allow us to characterize the vertical structure of the atmosphere over the coastal region and diagnose the PBL height at 12:00 UTC. Temperature, dewpoint temperature, relative humidity, pressure, wind speed and wind direction were measured.

Finally, LIDAR retrievals were routinely performed during the winter campaign over 25 characterize the vertical structure of the aerosol layers over Barcelona and their evolution. Following Sicard et al. (2006) the PBL height was also computed from the LIDAR profiles.

DAURE campaign

meteorological overview

O. Jorba et al.

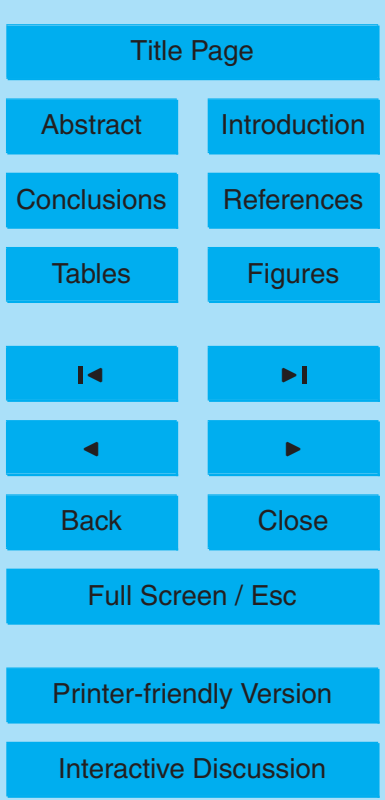


All the meteorological information was complemented by high resolution numerical weather prediction simulations provided by the BSC specially for the DAURE campaign. Model data are described in Sect. 2.2.

\subsection{Modelling results}

5 Apart from commonly used global meteorological forecasts from NCEP and ECMWF, high resolution numerical forecasts were made available to the DAURE campaign. Both meteorological and air quality forecasts were produced daily by the BSC over the area under study. The numerical modeling system is based on the CALIOPE project (Baldasano et al., 2008, http://www.bsc.es/caliope/). The system provides me10 teorological and air quality forecasts for Europe $\left(12 \times 12 \mathrm{~km}^{2}, 1 \mathrm{~h}\right)$, Spain $\left(4 \times 4 \mathrm{~km}^{2}\right.$, $1 \mathrm{~h})$ and the geographical area of Barcelona $\left(1 \times 1 \mathrm{~km}^{2}, 1 \mathrm{~h}\right)$. It includes the WRFARW/HERMES/CMAQ/BSC-DREAM8b system. Due to the geographical proximity of the Iberian Peninsula to the African continent, the area under study is highly influenced by Saharan dust outbreaks (Rodríguez et al., 2001, 2002; Pérez et al., 2006a). There15 fore, the modeling system takes also into account the contribution of mineral dust from Saharan desert to the particulate matter concentration. Within this context, the BSC also operates the model BSC-DREAM8b (Nickovic et al., 2001; Pérez et al., 2006b, http://www.bsc.es/projects/earthscience/DREAM/) to provide Saharan dust forecasts over the Mediterranean and southern and central Europe.

20 The products of the CALIOPE system include $24 \mathrm{~h}$ and $48 \mathrm{~h}$ forecasts for $\mathrm{O}_{3}, \mathrm{NO}_{2}$, $\mathrm{SO}_{2}, \mathrm{CO}, \mathrm{PM}_{10}$ and $\mathrm{PM}_{2.5}$ at surface level. In this framework, $\mathrm{PM}_{10}$ and $\mathrm{PM}_{2.5}$ products in all simulated domains are achieved adding the Saharan dust contribution from BSC-DREAM8b to the anthropogenic output of the chemical transport model of the CALIOPE system. Eleven different chemical aerosol components are distinguished

in CALIOPE, namely nitrates, sulphates, ammonium, elemental carbon, organic carbon with three subcomponents: primary, secondary anthropogenic and secondary biogenic, soil, sodium, chlorine and mineral dust. The modeling system uses a modal
11, 4953-5001, 2011

\section{DAURE campaign \\ meteorological overview}

O. Jorba et al.

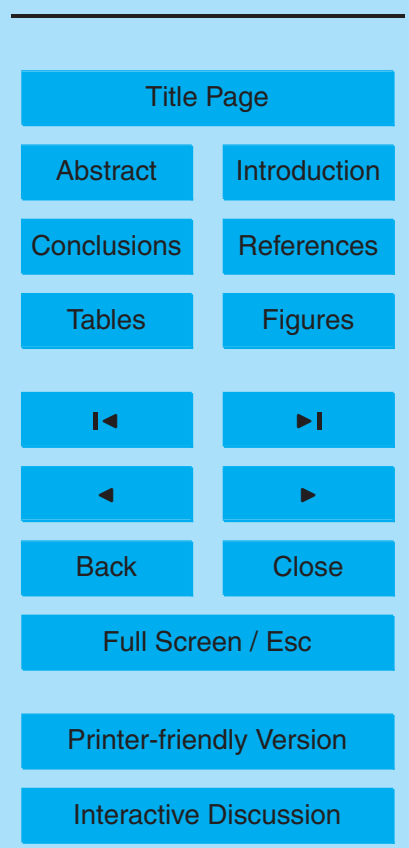

Interactive Discussion 
approach for the aerosols. Three modes are considered: Aitken, accumulation and coarse mode.

The Advanced Research Weather Research and Forecasting (WRF-ARW) Model v3.0.1.1 (Michalakes et al., 2004; Skamarock and Klemp, 2008) is used to provide de5 tailed mesoscale meteorological fields for the campaign. The model is configured with 38 sigma vertical layers from the surface up to $50 \mathrm{hPa}$, the model top. Microphysical processes are treated using the Single-moment 3-class scheme. The sub-grid-scale effects of convective and shallow clouds are resolved by a modified version of the Kain-Fritsch scheme for the European domain and are explicitly treated in the Iberian 10 peninsula and Barcelona domains. The Noah Land-Surface scheme is used to provide heat and moisture fluxes over land and sea-ice points. The vertical sub-grid-scale fluxes due to eddy transports in the atmospheric column are resolved by the Yonsei University PBL scheme. Finally, long-wave radiative processes are parameterized with the Rapid Radiative Transfer Model while the short-wave radiative scheme is based on the Dudhia SW scheme.

Additionally, for the present study, backwards Lagrangian particle dispersion calculations have also been performed with the FLEXPART-WRF model (Stohl et al., 1998; Fast and Easter, 2006; Doran et al., 2008). The model has been set-up with releases of 100000 computational particles within a grid cell of $10 \mathrm{~m} \times 10 \mathrm{~m} \times 10 \mathrm{~m}$ located $10 \mathrm{~m}$ a.g.I. at the MSY site. The dispersion model is driven by the meteorological simulations of the Iberian peninsula domain of the CALIOPE modeling system. In such configuration, the meteorology is given with a temporal resolution of $1 \mathrm{~h}$ and $4 \times 4 \mathrm{~km}^{2}$ horizontal resolution. The dispersion cloud is summarized with 5 clusters applying the k-mean clustering technique of Stohl et al. (2002) at 00:00, 06:00, 12:00 and 18:00 UTC arriving time. The length of the dispersion computation is $12 \mathrm{~h}$.

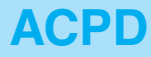

$11,4953-5001,2011$

\section{DAURE campaign meteorological overview}

O. Jorba et al.

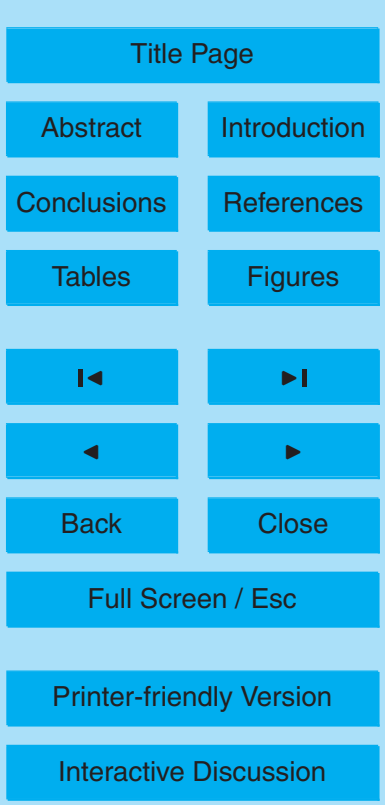




\section{Winter campaign}

\subsection{Synoptic-scale winter meteorological conditions}

The DAURE winter campaign was planned from 24 February to 27 March 2009. The main synoptic conditions in the NE Spain for the DAURE winter campaign are char-

5 acterized by the influence of high pressures from the continental anticyclone and the presence of traveling mid-latitude lows that can affect the Iberian Peninsula with the passage of frontal systems. This results in three main meteorological regimes for the winter campaign: a first regime dominated by high-pressure conditions over Barcelona and the western Mediterranean Basin, with high insolation, and with the development of thermally-driven wind flows; a second regime characterized by a strong northwestern advection that produces a cleansing action over the atmosphere, and, finally, a third regime dominated by strong nocturnal thermal inversions that decouple the low troposphere of plain and coastal areas from mountainous terrains.

Figure 5a shows the mean sea level pressure at 12:00 UTC and 6-h accumulated precipitation from the WRF-ARW forecasts. The start of the campaign is characterized by high pressures associated with a deep anticyclone located in southern Ireland, while a low pressure system affects Poland and northeastern Europe. Such configuration is characteristic of wintertime (e.g., Martín-Vide and Olcina, 2001). The Barcelona area presents clear skies, low wind speeds and large thermal daily cycle amplitude (Fig. 5).

The thermal stratification leads to the development of fogs in the inland valleys and depressions and the development of strong thermal inversions. These high pressure conditions are dominant until 1 March. Afterwards, the high pressures are displaced by the penetration of a deep low from north United Kingdom (UK). A cold front sweeps across the Iberian Peninsula, leading to a strong decrease of temperatures of $5-10^{\circ} \mathrm{C}$

in Barcelona and neighboring areas (Fig. 5). The 5 March is characterized by a north-

western advection with strong winds and precipitation on the northern coast of the Iberian Peninsula and Pyrenees (Figs. 5a and 5). The region of the DAURE campaign was affected by slight precipitation during the days previous to the frontal passage. The

DAURE campaign

meteorological overview

O. Jorba et al.

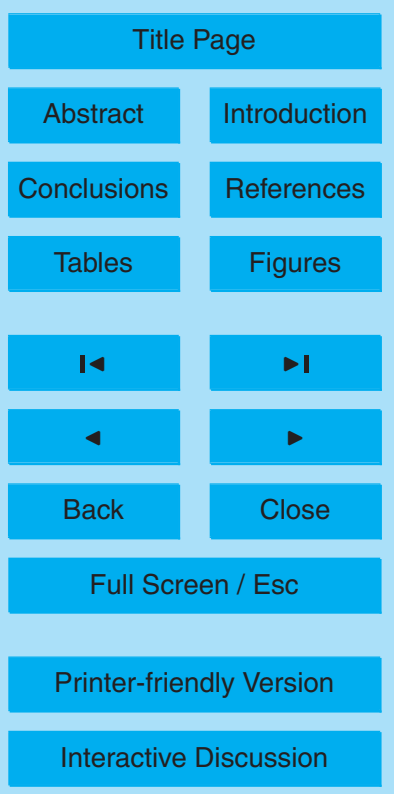


following days are characterized by clear skies and strong northwestern winds in the area under study. The synoptic situation evolves with a series of troughs and ridges propagating from west to east across central Europe from the 8 to 15 March. From 17 March, the jet stream undulates strongly and is positioned northward (not shown) 5 leading to the penetration of high pressures over central Europe. From 15 to 21 March a strong anticyclone over UK leads to high pressures dominating the situation over Western Europe whereas a low pressure gradient is observed over the study area. This produces several days of stable conditions with dominant mesoscale circulations. The high pressures over the region are dominant until 23 March. The Northern Atlantic 10 lows penetrate then again over Europe and push the high pressures southwards. The end of the campaign is characterized by a low pressure system affecting the southwest of Spain and northwestern air-masses flow over the BCN area. Precipitations are only observed at the end of 28 March and during the following day, but with low intensity.

During the winter campaign, Saharan dust outbreaks across the region are not 15 intense and do not substantially affect the Barcelona geographical area. Only on 28 February, 27 and 28 March significant dust events affect the northeastern Iberian Peninsula. For both episodes, the meteorological situation is characterized by a depression in southwestern Spain inducing southwesterly flows towards Barcelona area. Figure 5 presents the dust loading from the BSC-DREAM8b model for the two mentioned episodes. The air masses affecting the target domain contain dust loads between 0.05 and $0.3 \mathrm{~g} \mathrm{~m}^{-2}$. No significant precipitation is observed on 28 February, while the March episode includes some precipitation events. A low from mid-latitudes affects the Iberian Peninsula from north to south, advecting northern cold air masses. This configuration leads to an episode of general mild precipitations over NE Spain. 25 Neither of the dust outbreaks significantly contribute to the surface PM concentration levels.

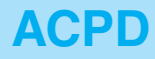

11, 4953-5001, 2011

\section{DAURE campaign \\ meteorological overview}

O. Jorba et al.

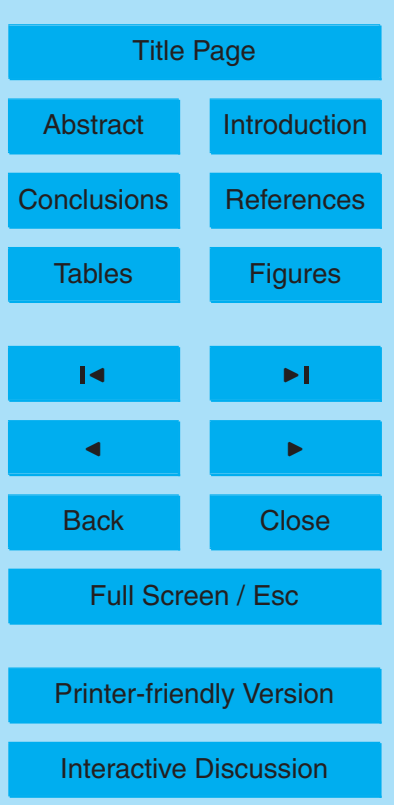




\subsection{Winter local conditions - mesoscale circulations}

Tables 1 and 2 summarize the main characteristics of the meteorological conditions for the winter DAURE campaign in the area under study (including the BCN and MSY sites). The thermal inversions are identified, the spatial average minimum and maxi5 mum temperatures, solar irradiance, daily precipitation and sea level pressure are computed from meteorological stations within the target area. Moreover, Table 2 presents the cloud coverage at 12:00 UTC over the BCN site, and the wind direction and speed at surface and $850 \mathrm{hPa}$ height from the Barcelona radiosounding. Finally, the PBL height at noon is computed from the 12:00 UTC Barcelona radiosounding.

10 The first remarkable feature is the significant decoupling of the lower from the middle troposphere, already described by Jorba et al. (2004). The synoptical forcing over the area under study presents a general northwestern direction (7th column of Table 2), whereas surface wind fields evolve through a daily cycle of nocturnal offshore flows to diurnal sea-breeze regimes during several days. The coastal sea-breeze regime does 15 not have the intensity of summer episodes, but it is strong enough to advect coastal air masses several kilometers inland. The circulation system is reinforced by thermally driven flows, up-valley and up-slope winds.

As an example, Fig. 5 shows two characteristic situations which occurred during the DAURE campaign. The first one (Fig. 5a,b) shows the wind field at 04:00 UTC and 14:00 UTC modeled with the high-resolution meteorological model WRF-ARW, where a clear day-night thermal pattern can be identified. The sea breeze circulation develops around 10:00 UTC with a marked SW direction at surface levels. A combination of sea breeze and upslope winds contribute to the inland advection of the coastal air masses. The topography of the region therefore plays an important role by inducing the orographic forcing of the flows which may be channeled along valleys or injected aloft.

In Fig. 5cd a surface NE daily situation is also shown. Even though the surface temperature is warmer for 17 March, the thermally driven flows are more intense during

\section{ACPD}

11, 4953-5001, 2011

\section{DAURE campaign \\ meteorological overview}

O. Jorba et al.

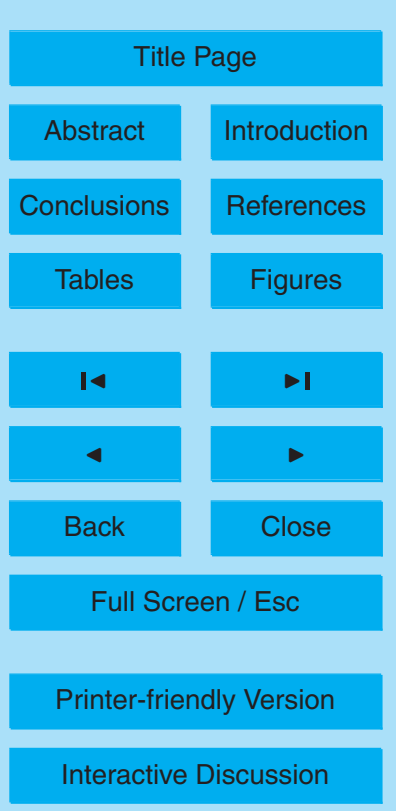

Interactive Discussion 
26 February due to the synoptic forcing. Most of the winter campaign is characterized with clear sky conditions. Only the periods from 27 February to 3 March, 8 and 9 March and 28 to 30 March are cloudy days. The mean daily solar irradiance over the region for the winter campaign is $14.6 \mathrm{MJ} \mathrm{m}^{-2}$.

5 The time series of wind, temperature, relative humidity, incoming solar radiation and surface pressure at Barcelona are plotted in the meteogram of Fig. 5. According to the previous section, the evolution of surface pressure clearly correlate with the main synoptic patterns affecting the region during the winter campaign. The start of the campaign is characterized by clear skies covered with some scattered non-precipitating thin 10 clouds. The temperature and relative humidity evolve with a clear daily cycle during the first week. The onshore winds blow moist air masses inland during daytime, while the wind veers northward during nighttime with weak intensity. The southwestern advection of 28 February modifies the established pattern. In the middle troposphere a SW-NE cold trough travels over Spain from 28 February to 4 March. A clear decrease in sur15 face temperatures is observed in the BCN and MSY sites. This situation is associated with the development of a depression in the southwest of Spain that affects the peninsula and some precipitation events are observed in BCN and MSY. This situation is followed by a strong northwestern advection, from 5 to 7 March. The northwestern advection produces a marked drop in the temperature and relative humidity and clears the cloudy sky for the following days. After the northwestern event, the low baric gradient settles over the western Mediterranean basin. Hence, the development of mesoscale phenomena in the Barcelona area dominates again. The Barcelona station shows a clear sea-breeze regime from 12 to 27 March. The intensity of the sea-breeze varies from 4 to $6 \mathrm{~m} \mathrm{~s}^{-1}$ with southwestern direction during daytime whereas the wind tends to weaken during the night. This pattern is modified at the end of the winter campaign by another SW advection situation associated with some precipitation (28 March).

As stated already above, the winter campaign is not affected by noticeable precipitation events. The meteorological stations record a light episode from 1 to 4 February, a second event on 6 March and a last one at the end of the campaign, on 28 and

\section{ACPD}

$11,4953-5001,2011$

\section{DAURE campaign \\ meteorological overview}

O. Jorba et al.

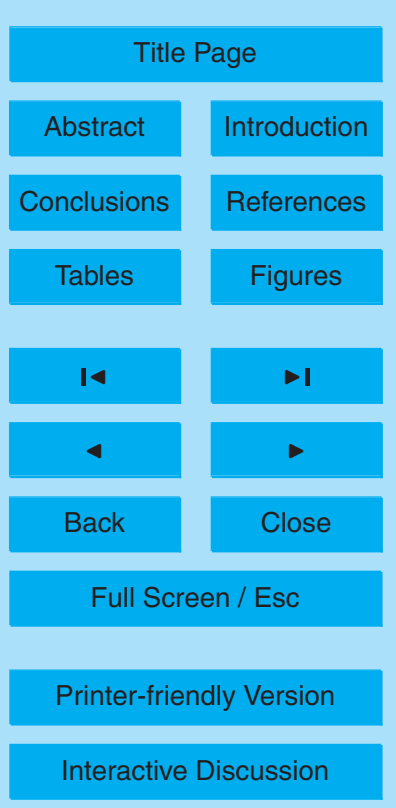

Interactive Discussion 
29 March. The total amount of precipitation does not exceed $10 \mathrm{~mm}$ of $24-\mathrm{h}$ accumulated precipitation across the area under study.

Concerning the MSY site (Fig. 5), there is a significant difference in winds between the first and second half of the campaign. In the first case, low winds characterize this 5 period of moderate calm until the frontal passage. The two main wind directions along SE-NW follow the valley axis and confirm the channeling of the flow within it. During the second half of the campaign, stronger winds from SE during midday are able to transport airmasses from longer distances, including the coastal area. There are some days where the relative humidity at the MSY site is around $100 \%$. This indicates that the 10 site is above the level of cloud development. It is a common feature during wintertime. The days 2 to 5 March, 10 March and at the end of the campaign are characterized by this feature.

It is important to highlight the strength of nocturnal thermal inversions. Table 1 presents the difference of the minimum nocturnal temperature between four 15 sites: MSY, prelitoral depression, Tibidabo (litoral mountain range) and BCN. The temperature inversion is classified into four categories $\left(T 1: \Delta T / \Delta Z<0.005 \mathrm{~K} \mathrm{~m}^{-1}\right.$; T2: $0.005 \mathrm{Km}^{-1}<\Delta T / \Delta Z<0.01 \mathrm{Km}^{-1} ; T 3: 0.01 \mathrm{Km}^{-1}<\Delta T / \Delta Z<0.02 \mathrm{Km}^{-1} ; T 4$ : $\Delta T / \Delta Z>0.02 \mathrm{~K} \mathrm{~m}^{-1}$ ). Such a classification permits us to characterize the strength of the nocturnal thermal inversion between mountain, valley and coastal sites. Furthermore, Fig. 5 shows the evolution of the measured surface temperature and relative humidity at three meteorological stations. One is located at the coast - Barcelona station (X8), 85 m a.s.l., green line - a second one is located at the Pre-coastal depression, between coastal mountain range and Montseny mountains - Caldes de Montbui station (X9), 176 ma.s.l., blue line - and a last station is at the Montseny mountain - Tagamanent station (VX), 990 ma.s.l., red line. Figure 1 shows the location of the three stations. The evolution of the temperature and relative humidity normally shows periods where the temperature at Montseny is colder than those observed at the coast and the Pre-coastal depression, as expected considering the height difference between the Montseny station and the other two. However, some periods where

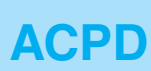

$11,4953-5001,2011$

\section{DAURE campaign \\ meteorological overview}

O. Jorba et al.

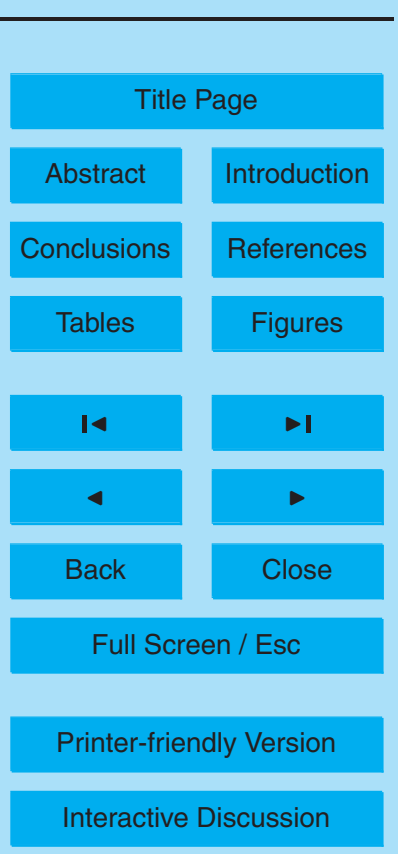

Interactive Discussion 
clear strong thermal inversion establishes are clearly visible. From late 26 February to 1 March 2009 there is a marked drop of the relative humidity in the Montseny, and the temperatures are largely warmer at the mountain top than at the valleys and plane regions. While the Montseny station measures a nocturnal temperature of $10^{\circ} \mathrm{C}$ during 528 February, the temperature in Caldes de Montbui station is below $5^{\circ} \mathrm{C}$. This nocturnal thermal inversion scenario lasts until 1 March 2009. The thermal inversion during this period is classified as a $T 2, T 3$ and $T 4$ strength in Table 1 . This strong inversion produces a clear decoupling of the lower air masses of the coastal and valley regions from the mountain top at Montseny. The formation of a strong nocturnal inversion, with 10 strengths of $T 2$ and T4, is also found in some episodes during March, e.g., 13 March to 16 March 2009. There are also other days where the nocturnal thermal inversion is detected as well, although with a lower strength, $T 1$ in the aforementioned classification of Table 1. The translation of these specific meteorological conditions into the DAURE particulate matter measurements is: low concentrations at the MSY and still 15 high concentration measured at the BCN site. From the DAURE particulate matter measurements, these episodes are associated with low concentrations of particulate matter at Montseny station while the BCN site still measures high concentrations of PM (Pandolfi et al., 2011). This behavior can be explained by the development of strong thermal inversions over the region and a limited vertical development of the PBL during 20 the day.

The evolution of the PBL for the DAURE campaign over the BCN site has been assessed with radiosoundings and LIDAR profiles. For the retrieval of the mixing height we use the Parcel method (Stull, 1988) for the radiosoundings and Sicard et al. (2006) for the LIDAR profiles. The reader is referred to Pandolfi et al. (2011) for a detailed description of the PBL height retrievals from radiosoundings. Figure 5 shows the mixing height at 12:00 UTC from the radiosounding and from the LIDAR at specific hours. The PBL height evolution during the winter campaign presents heights in agreement with those obtained by Sicard et al. (2006). The mixing height over Barcelona normally remains below 1000 ma.s.l. There are also some periods within the campaign
ACPD

$11,4953-5001,2011$

DAURE campaign

meteorological overview

O. Jorba et al.

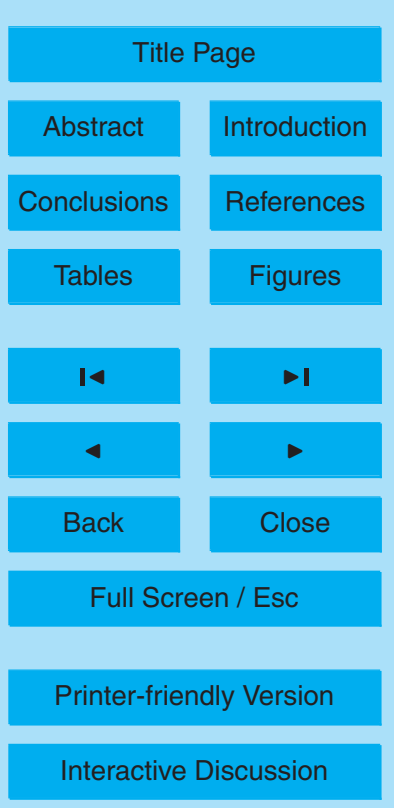


that shows a PBL above $1200 \mathrm{~m}$ a.s.l. Considering that the sea-breeze front develops at 10:00-12:00 UTC it is normal to observe a lamination of the mixing layer with the entrance of the on-shore flow over Barcelona (Pérez et al., 2004) that leads to a shallow mixing height. It is important to highlight the days where the PBL at BCN remains 5 below $700 \mathrm{~m}$ (see Table 2 and Fig. 5). Under these situations, the accumulation of pollutants within the Barcelona boundary layer is enhanced by the low development of the PBL.

In order to determine the origin and local pathways of air masses arriving at the MSY site, the FLEXPART-WRF model has been applied. As described in Sect. 2.2, the 10 model was set-up to provide a synthetic clustered output of the particle cloud dispersion. Five clusters of backtrajectories are used to represent the dispersive conditions affecting the area under study. From these results, each day of the winter campaign has been classified according to the main transport patterns identified in the dispersion calculations (see last column of Table 2). In agreement with the synoptic description seven different situations are identified: (A) stagnant conditions with daily SW seabreeze development, (B) stagnant conditions with daily SE sea-breeze development, (pC) previous cloudy days to northern advection with weak precipitation, (C) northern advection, (D) any situation with strong nocturnal thermal inversion, (E) southern advections, and $(F)$ western-northwestern advections. From this classification the large occurrence (around 35\% of the days) of strong thermal inversions during the campaign can be appreciated. Also, situation A and $C$ have been identified in $30 \%$ the days, and $\mathrm{F}$ scenario represents around $17 \%$ of the days.

The cluster-backtrajectories for some representative days of $A, A-D, C$ and $F$ situations are shown in Fig. 5. The backtrajectories are plotted every $15 \mathrm{~min}$ and colored with the height of the air mass in ma.g.I. The backtrajectory results at 00:00, 06:00, 12:00 and 18:00 UTC are shown. The 24 February case, which has been classified as a situation A (Fig. 5, upper panels), is characterized by weak southern advection during nighttime. Air masses move between the BCN site and the MSY site slowly. The air parcel travels at low-medium height, below $600 \mathrm{~m}$ a.g.l. With the development of the
ACPD

$11,4953-5001,2011$

\section{DAURE campaign \\ meteorological overview}

O. Jorba et al.

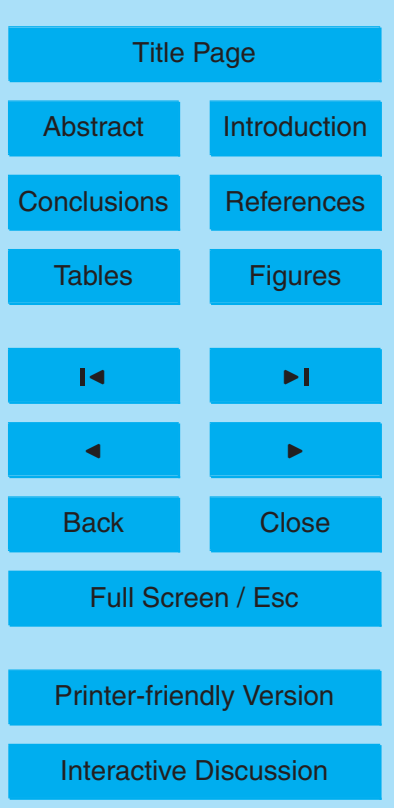


PBL the southern flows affecting the MSY site are clearly established. It is important to note some northern air masses arriving at higher altitudes completely decoupled from southern surface flows. The last backtrajectory (18:00 UTC) shows how the air masses arrive at the MSY site from northeast, with an origin in the northeast of the area under during the first half of the day with a posterior veering of the flows to a northeast component. A similar situation is found in 15 March 2009 (A-D situation in Fig. 5). The main difference between both days is the strong nocturnal capping inversion limiting the advection of coastal air masses to the MSY site. Backtrajectories at 00:00 and

06:00 UTC show a calm situation where air masses come from near east and north regions from the MSY site. Hence, BCN air masses do not affect the MSY site during nighttime. The backtrajectories at noon indicate that the MSY site is still decoupled from the $\mathrm{BCN}$ air masses, where the air parcels have a mediterranean origin coming from the southwest. Only results at 18:00 UTC show two cluster-backtrajectories traveling from BCN to the MSY site at surface layers, whereas most of the air comes from upper levels with western direction.

Another clear situation is 5 March 2009 (C situation in Fig. 5). The day corresponds to a clear NW advection scenario, where the MSY site is affected by northwestern flows. This situation produces a cleansing effect on MSY site and also over all NE Spain.
Finally, 10 March 2009 is a F situation characterized by western flows during daytime and some nocturnal circulations from BCN to the MSY site at low levels.

From all the situations, those characterized by the influence of BCN air masses to MSY are A, B and E. However, when strong nocturnal inversion is present (D situation), any scenario shows a clear decoupling of the BCN and MSY site air masses.

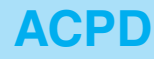

11, 4953-5001, 2011

\section{DAURE campaign meteorological overview}

O. Jorba et al.

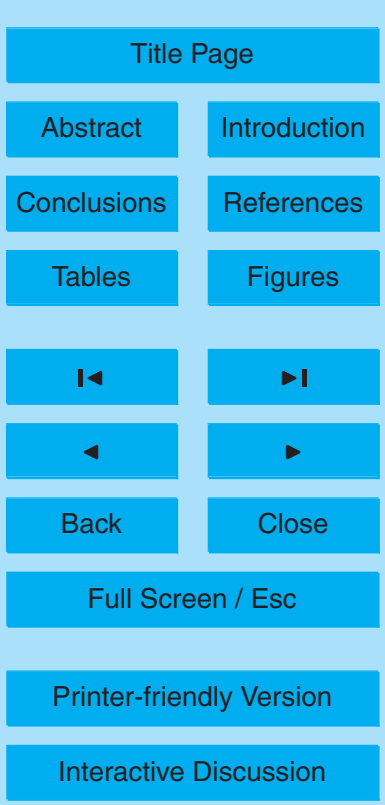




\section{Summer campaign}

\subsection{Synoptic summer conditions}

The mean sea level pressure and 6-h accumulated precipitation from the WRF-ARW high-resolution forecasts are shown in Fig. 5. The high-pressure associated to the

5 Azores anticyclone wedge dominates northeastern Spain. The Atlantic low pressures only affect northern latitudes, veering NE when approaching the European continent. This synoptic structure leads to the establishment of a low pressure gradient situation over the Iberian Peninsula and the WMB. Only three episodes modify the main stationary synoptic conditions. The first one covers the period from 7 to 11 July. It is char10 acterized by an important thunderstorm activity offshore the eastern coast of Spain. Cumulus clouds strongly develop during daytime and intense precipitation events are produced over the sea. Inland, the precipitation is measured only on 6 and 7 in the MSY and 9 July in the BCN site during midday. The two other situations, 14 and 22 July, are characterized by frontal passages. Both are characterized by a deep low crossing Ireland and UK and moving forwards with a cold front extending southward and affecting the Iberian peninsula. No precipitation is measured over NE Spain, but a slight decrease in temperatures is observed. Moreover, this two situations are associated with SW flows affecting the WMB and, as will be describe below, Saharan dust outbreaks affect the area under study.

20 During most of the summer campaign, mesoscale phenomena dominate the atmospheric dynamics over the area, with development of sea-breeze circulations and thermally driven flows inland. The high insolation and warm temperatures contribute to the development of sea-breeze flow regimes. The cloudiness is not prominent during morning and afternoon, cumulus clouds develop during the evenings over the coastal and pre-coastal mountain ranges enhanced by the moist air advected by the seabreeze front. The next section discusses in more detail the circulations developed over the region.

DAURE campaign meteorological overview

O. Jorba et al.

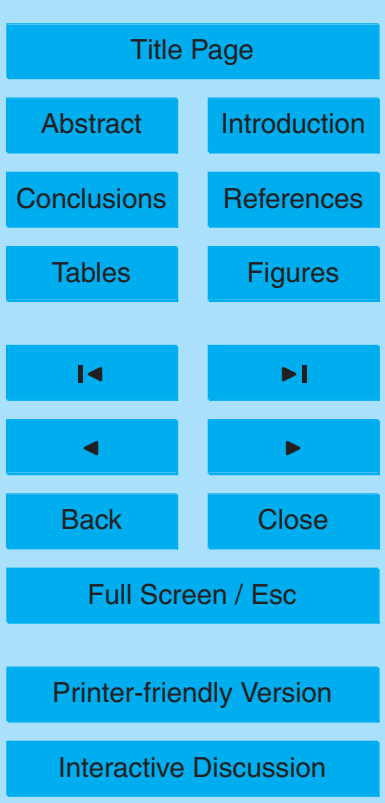

Interactive Discussion 
Concerning long-range transport of mineral dust towards NE Spain, three main episodes are identified. A first dust outbreak is observed on 14 July (Fig. 5). In this occasion, warm air masses penetrate the NE Spain from southward direction with modeled dust loads of $0.5 \mathrm{~g} \mathrm{~m}^{-2}$ and the WMB between 1 and $2.5 \mathrm{~g} \mathrm{~m}^{-2}$ (results from BSCDREAM8b model). The situation evolves to a second minor dust outbreak on 16 July, where the BSC-DREAM8b model simulates a dust load of $0.25 \mathrm{~g} \mathrm{~m}^{-2}$ at $12: 00$ UTC.

The second relevant episode occurs from 20 to 23 July. In this case, a strong anticyclonic circulation develops over central Algeria. The resultant SW winds advect dust loads towards the southern Iberian Peninsula, reaching NE Spain on 21 July 2009 at 10 00:00 UTC. The BSC-DREAM8b model simulates the highest dust load $\left(1 \mathrm{~g} \mathrm{~m}^{-2}\right)$ on 23 July at 00:00 UTC over NE Spain.

The last episode in July is produced between 26 to 28 July. Within this episode, the dust load over north Africa is large and well extended. A cyclonic circulation develops over east Canary Island while an anticyclonic circulation establishes over north Algeria. Such configuration contributes to the advection of air masses with significant dust concentrations $\left(1 \mathrm{~g} \mathrm{~m}^{-2}\right)$ following a southwest-northeast direction. Enriched dust air masses affect NE Spain at 12:00 UTC 26 July until 28 July.

\subsection{Summer local conditions}

During summer the Mediterranean regions normally experience higher temperatures, 20 greater amounts of sunshine and fewer rainy days than western and central Europe (Salvador et al., 1997). The pressure system that dominates the region is the Azores anticyclone, which contributes to the development of large thermally driven convective systems over the Iberian Peninsula and land-sea breezes over the coasts.

Several authors have described the dynamics and flow recirculations produced along 25 the WMB (e.g., Baldasano et al., 1994; Millán et al., 1997; Soriano et al., 2001; Jorba et al., 2004; Pérez et al., 2004). During the day the sea breezes combine with upslope winds and transport coastal pollutants inland, while, at the leading edge of the breeze front, a large fraction of these pollutants are injected into their return flows aloft at

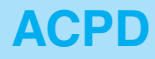

$11,4953-5001,2011$

\section{DAURE campaign \\ meteorological overview}

O. Jorba et al.

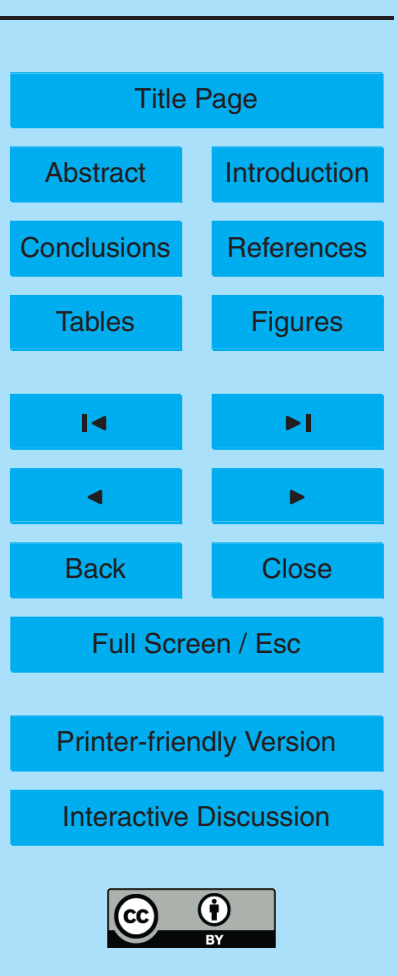


heights ranging from 2 to $3 \mathrm{~km}$. Once in those upper layers, the pollutants move back toward the sea, and the compensatory subsidence associated to the thermal Iberian low (Millán et al., 1997) creates stratified reservoir layers of aged pollutants, stacked up to $2-3 \mathrm{~km}$ high, along the coast over the sea. These layers act as reservoirs and 5 may retain pollutants from one day to the following days. Therefore, the next morning the lowermost layers are drawn inland by the sea breeze when the aged pollutants can react with new coastal emissions.

A summary of the main meteorological conditions for the summer campaign is presented in Tables 3 and 4. Both tables present the same information as Tables 1 and 2 10 for the summer campaign. The spatial averaged maximum temperature varies around $30^{\circ} \mathrm{C}$ and $35^{\circ} \mathrm{C}$ for all the summer campaign and the minimum temperature is maintained near $20^{\circ} \mathrm{C}$. The episode from 7 to 11 July shows a significant decrease of the maximum temperatures of $10^{\circ} \mathrm{C}$. Regarding the synoptic winds, there is a clear persistence of S-SW direction at $850 \mathrm{hPa}$ while at the surface, the land-sea breeze domi15 nates the daily cycle.

As can be seen in Fig. 5, the BCN meteogram shows typical daily patterns excepting those days affected by the thunderstorm activity and the frontal passage. The maximum temperature is observed at noon when the see breeze is well established. The sea level pressure in $\mathrm{BCN}$ varies between $1000-1008 \mathrm{hPa}$ during the entire summer campaign, indicating the persistence of stagnant conditions. A typical daily evolution of the surface wind field is presented in Fig. 5. A well developed sea-breeze regime is established along the entire coast of the Barcelona geographical area. This regime covers the central hours of the day, starting around 08:00-10:00 UTC and changing to a land-sea flow around 19:00 UTC. The strongest sea breezes form during the second 25 half of the campaign, with wind speeds reaching $5 \mathrm{~m} \mathrm{~s}^{-1}$ at its full development time. At 12:00 UTC, the breeze has reached the first mountainous chain producing important orographic injections. A common characteristic of this situation is the permanent entrance of air masses by the Pyrenees-Massif Central canalization and the anticyclonic circulation at surface layers over the WMB maintained all day. A closer look into the

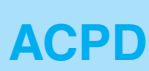

11, 4953-5001, 2011

\section{DAURE campaign \\ meteorological overview}

O. Jorba et al.

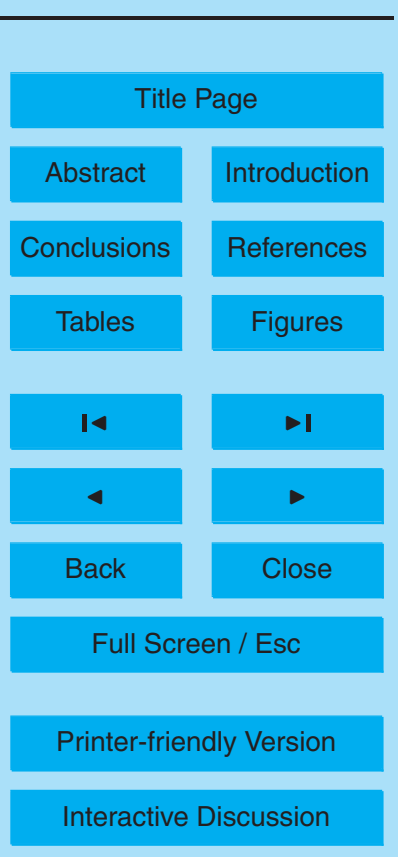


nocturnal evolution of the wind regime shows an offshore wind established along the coastal zone (land-breeze development). Inland, the downslope winds are also well established.

At the MSY site (Fig. 5), the flows are well channeled along the main valley axis 5 SE-NW. During the day, the air masses from the coastal areas travel inland enhanced by the sea breeze and the up-valley flow. During the night the reverse flow moves towards the coastal area reinforced by the katabatic winds from the tributary valleys of the mountain range.

Table 4 presents the PBL heights at noon over Barcelona for the summer campaign. 10 The mixing height usually ranges from 500 to $1500 \mathrm{~m}$. Episodes associated with convective activity and mesolow development offshore the eastern coast of Spain present masked PBL heights (e.g., 7, 9 or 23 July).

As in the winter campaign, we have computed backward Lagrangian simulations to characterize the air masses arriving at the MSY site. For the summer campaign, the 15 results allow us to identify five recurrent situations: $(A)$ thermally driven land-see flows, (B) thunderstorm event, (C) eastern see-breeze regime, (D) western advection, and (E) southwestern advection with Saharan dust outbreak affecting the area under study. Synoptic conditions of cases A, B, C and D are characterized by low pressure gradients over the WMB as discussed before, while E conditions show clear SW synoptic flows.

20 The higher occurrence situation is case $A$ with a $50 \%$, then $E$ scenario, in $25 \%$ of the cases, and $B$ scenario in $18 \%$. $C$ and $D$ are only observed one day.

An example scenario of $A, C, D$ and $E$ situations are shown in Fig. 5. The clusterbacktrajectories computed at 00:00, 06:00, 12:00, 18:00 UTC arrival time are arranged from left to right. The A scenario is a typical situation of thermally driven flows. The air 25 masses affecting MSY site during nighttime come from the NE. The nocturnal winds are weak to calm and intensify with the sunrise. Trajectories at 12:00 UTC clearly describe a see-breeze pattern. The maritime air masses are transported with the seebreeze flow from BCN and coastal areas inland until the MSY site. The veering of the see-breeze is also appreciable in 18:00 UTC cluster-backtrajectories, when the MSY is

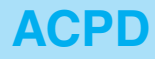

$11,4953-5001,2011$

\section{DAURE campaign \\ meteorological overview}

O. Jorba et al.

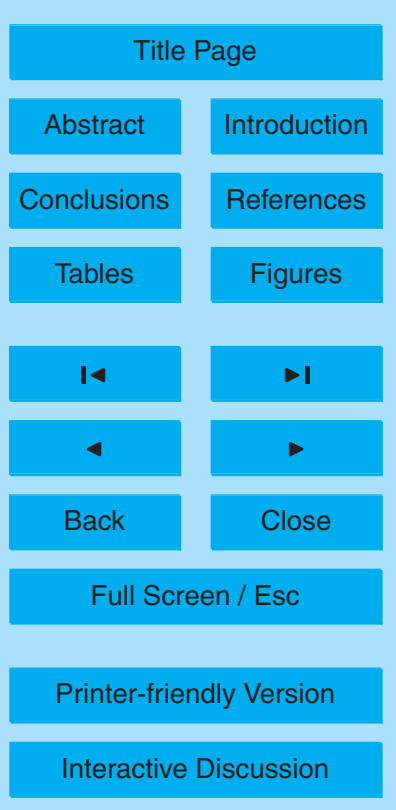


reached by northeastern air masses. A similar scenario is found in the 16 July 2009 event ( $C$ situation in Fig. 5). Again, nocturnal trajectories show a prevalence of stagnant conditions. The development of the sea-breeze advects coastal air parcels to the MSY site. A large number of the simulated particles are channeled through the Pre-litoral 5 depression with a marked NE direction before arriving at the MSY site. Results at 18:00 UTC present a well established sea-breeze structure. Therefore, the MSY site is affected by the BCN and highly urbanized areas of Pre-litoral depression air masses.

On the other hand, zonal advective situations are characterized by some decoupling of the MSY and the BCN air masses. An example of the D situation occurs on 1021 July 2009 (Fig. 5). The zonal advection is already present during the nighttime and lasts until the evening, with air parcels travelling along the southern slopes of the Pyrenees towards the MSY site. Also some NW aloft flows reach the MSY site. Only in the evening, some air masses from surface layers affect MSY from coastal areas including the BCN site. Lastly, another clear advective situtation is 21 July 2009 (E situation in Fig. 5). The SW synoptic flow dominates the whole day. Under these conditions, some Saharan air masses with significant dust load may reach NE Spain as described before. In this case, the nocturnal hours exhibit a western veering of flows just before affecting the MSY site. This indicates that during nighttime, BCN air masses do not reach the MSY site. However, during daytime, where the land heating is strong enough to develop thermally driven flows, BCN air masses are advected with the sea-breeze towards the MSY site.

From all the previous discussion we can identify those days where MSY site is affected by some polluted areas (e.g., BCN). Such conditions occur in A and E scenarios, while $B, C$ and $D$ scenarios may be characterized by a clear decoupling of the air

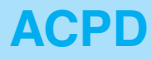

$11,4953-5001,2011$

\section{DAURE campaign \\ meteorological overview}

O. Jorba et al.

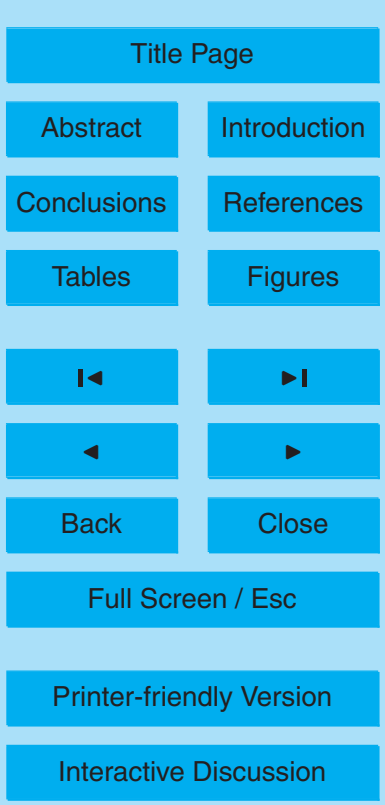




\section{Summary and conclusions}

The DAURE campaigns were held in February, March and July 2009 over NE Spain. The main objective of DAURE is to further understand the origin and sources of particulate matter in NE Spain. The campaigns had two main experimental sites - an 5 urban one located in Barcelona city, and a rural site at the Montseny natural park. Understanding the meteorology during the campaigns plays a key role for posterior measurement interpretation. Both synoptic and local phenomenology has been described to take into account transport processes that affect the air mass properties and composition, and, therefore, aerosol properties. Meteorological information has been obtained from local instrumented stations and modeling simulations. Mean sea level pressure and precipitation fields, as well as wind fields have been obtained for each day of the campaigns. Backward Lagrangian particle dispersion simulations have been performed to identify the local pathways of air masses reaching the MSY site. Also, dust loading maps have confirmed the dust outbreaks events taking place during 15 the campaigns. Characterization of the vertical structure of the atmosphere, (i.e. mixing layer height) was based on soundings and LIDAR measurements. High-resolution meteorological and air-quality forecasts were provided during the campaign.

From all this information, an analysis of the meteorological patterns and characteristics for the campaign has been performed. This analysis permits us to identify three main meteorological regimes for the winter campaign: (1) a first regime dominated by high-pressure stability conditions over Barcelona and WMB, high insolation, and development of thermally-driven wind flows; (2) a second regime characterized by a strong northern advection that produced a cleansing action over the atmosphere; (3) and a third regime dominated by strong nocturnal thermal inversions that decouple the low troposphere of plane and coastal areas form mountainous terrains.

DAURE campaign

meteorological overview

O. Jorba et al.

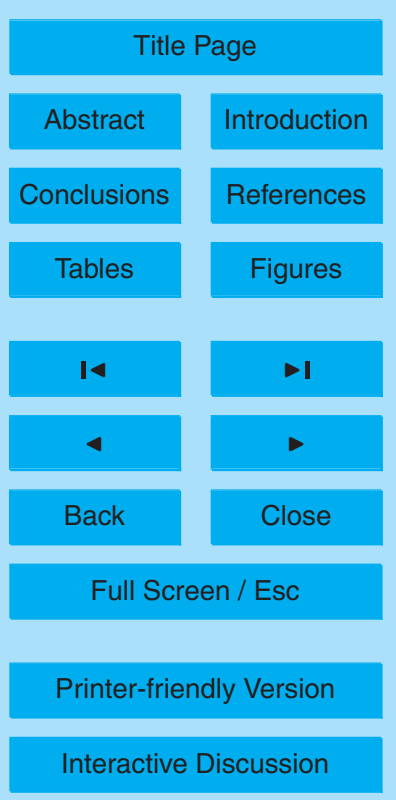


Accordingly, the main meteorological regimes identified for the summer campaign are: (1) a typical summer recirculation pattern, with low pressure gradients over the WMB, with high insolation and developments of mesoscale features; (2) a second pattern characterized by the advection of southern air masses enriched with mineral dust 5 form North Africa; (3) and a third zonal advective scenario associated with frontal zones that inhibits the mesoscale circulations and leads to some precipitating events over NE Spain.

All of this information provides a comprehensive picture of the state and evolution of the atmosphere in the study area during the measurement periods. This article repre10 sents a reference concerning the description of the meteorological conditions occurred during the DAURE campaign.

Acknowledgements. The authors wish to thank the Catalan Meteorological Service for providing the surface meteorological observations and the Barcelona radiosounding data. Also, special thanks to Jerome Fast for providing the FLEXPART-WRF code, to Jose-Luis Jimenez 15 for the efforts coordinating the DAURE campaign and to Don Morton for the revision of the manuscript. This work is partially funded by grants CGL2007-30502-E/CLI, CGL200802818-E/CLI, CGL2008-02817-E/CLI, CGL2008-01330-E/CLI, CGL2009-08031-E/CLI, GRACCIE CONSOLIDER Project (CSD2007:00067) of the Spanish Ministry of Science and Innovation and CALIOPE project of the Spanish Ministry of the Environment (441/2006/3-12.1,

20 A357/2007/2-12.1, 157/PC08/3-12.0). M. A. Revuelta acknowledges the Ministry of Science and Innovation for their economical support through the FPI predoctoral grant BES-2008007079. All simulations were performed on the MareNostrum supercomputer hosted by the Barcelona Supercomputing Center.

\section{ACPD}

$11,4953-5001,2011$

\section{DAURE campaign meteorological overview}

O. Jorba et al.

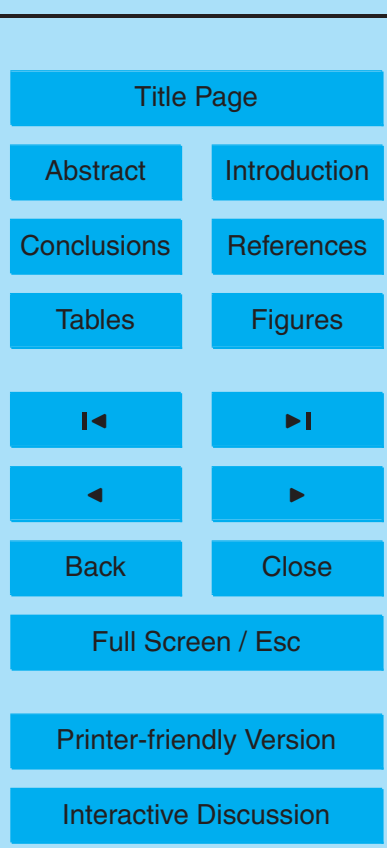




\section{References}

Baldasano, J. M., Cremades, L., and Soriano, C.: Circulation of air pollutants over the Barcelona geographical area in summer, in: 6th European Symposium PhysicoChemical Behaviour of Atmospheric Pollutants, 18-22 October, Varese, Italy, 1993, Report $5 \quad$ EUR 15609/1, 474-479, 1994. 4971

Baldasano, J. M., Jiménez-Guerrero, P., Jorba, O., Pérez, C., López, E., Güereca, P., Martín, F., Vivanco, M. G., Palomino, I., Querol, X., Pandolfi, M., Sanz, M. J., and Diéguez, J. J.: Caliope: an operational air quality forecasting system for the Iberian Peninsula, Balearic Islands and Canary Islands - first annual evaluation and ongoing developments, Adv. Sci. Res., 2, 89-98, 2008. 4960

Clavero, P., Martín-Vide, J., and Raso, J.: Atles climatic de Catalunya, Ed. Institut Cartografic de Catalunya, Alianza, 1997. 4957

deCarlo, P. F., Kimmel, J. R., Trimborn, A., Northway, M. J., Jayne, J. T., Aiken, A. C., Gonin, M., Fuhrer, K., Horvath, T., Docherty, K. S., Worsnop, D. R., and Jimenez, J. L.: FieldDeployable, High-Resolution, Time-of-Flight Aerosol Mass Spectrometer, Anal. Chem., 78, 8281-8289, 2006. 4959

Doran, J. C., Fast, J. D., Barnard, J. C., Laskin, A., Desyaterik, Y., and Gilles, M. K.: Applications of lagrangian dispersion modeling to the analysis of changes in the specific absorption of elemental carbon, Atmos. Chem. Phys., 8, 1377-1389, doi:10.5194/acp-8-1377-2008, 2008. 4961

Fast, J. and Easter, R.: A Lagrangian particle dispersion model compatible with WRF, in: 7th WRF Users Workshop, NCAR, 19-22 June, Boulder, Colorado, 2006. 4961

IPCC: Climate Change 2007: Synthesis Report, in: Intergovernmental Panel on Climate Change, edited by: Pachauri, R. K. and Reisinger, A., Geneva, Switzerland, 2007. 4956

25 Jimenez, J. L., Cocker, D. R., Bahreini, R., Zhuang, H., Varutbangkul, V., Flagan, R. C., Seinfeld, J. H., O'Dowd, C., and Hoffmann, T.: New particle formation from photooxidation of diiodomethane $\left(\mathrm{CH}_{2} \mathrm{I}_{2}\right)$, J. Geophys. Res., 108, 4318, doi:10.1029/2002JD002452, 2003. 4959

Jorba, O., Pérez, C., Rocadenbosch, F., and Baldasano, J.: Cluster Analysis of 4-Day Back Trajectories Arriving in the Barcelona Area (Spain) from 1997 to 2002, J. Appl. Meteorol., 43, 887-901, 2004. 4964, 4971

\section{ACPD}

$11,4953-5001,2011$

\section{DAURE campaign meteorological overview}

O. Jorba et al.

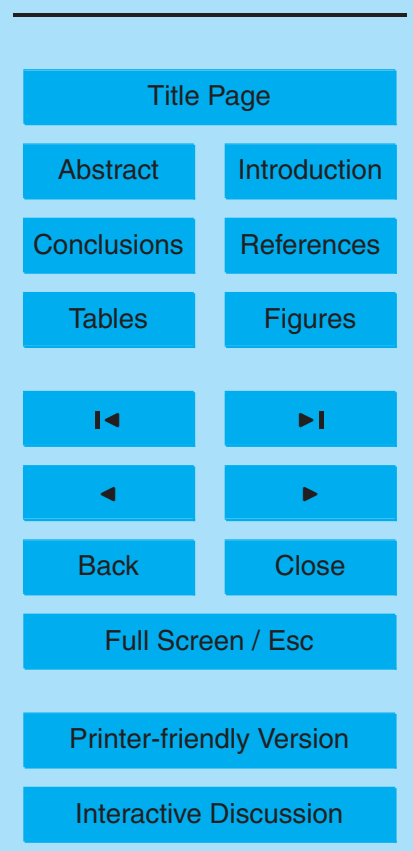


Lanz, V. A., Alfarra, M. R., Baltensperger, U., Buchmann, B., Hueglin, C., and Prévôt, A. S. $\mathrm{H}$.: Source apportionment of submicron organic aerosols at an urban site by factor analytical modelling of aerosol mass spectra, Atmos. Chem. Phys., 7, 1503-1522, doi:10.5194/acp-71503-2007, 2007. 4959

5 Martín-Vide, J. and Olcina, J.: Climas y tiempos de España, Ed. Alianza, 2001. 4962

Michalakes, J., Dudhia, J., Gill, D., Henderson, T., Klemp, J., Skamarock, W., and Wang, W.: The Weather Research and Forecast Model: Software Architecture and Performance, in: To appear in proceeding of the Eleventh ECMWF Workshop on the Use of High Performance Computing in Meteorology, edited by: Mozdzynski, E. G., 25-29 October 2004, Reading, $10 \quad$ UK, 117-124, 2004. 4961

Millán, M. M., Salvador, R., Mantilla, E., and Kallos, G.: Photooxidant dynamics in the Mediterranean basin in summer: Results from European research projects, J. Geophys. Res., 102, 8811-8823, 1997. 4971, 4972

Nickovic, S., Kallos, G., Papadopoulos, A., and Kakaliagou, O.: A model for prediction 15 of desert dust cycle in the atmosphere, J. Geophys. Res., 106 (D16), 18113-18129, doi:10.1029/2000JD900794, 2001. 4960

Pandolfi, M., Querol, X., Alastuey, A., Jimenez, J., Jorba, O., Stohl, A., Comerón, A., Sicard, M., Pey, J., vanDrooge, B., and the DAURE team: Source and origin of PM in the Western Mediterranean Basin: An Overview of the DAURE campaign, Atmos. Chem. Phys. Discuss.,

20 in preparation, 2011. 4956, 4959, 4967

Pérez, C., Sicard, M., Jorba, O., Comerón, A., and Baldasano, J. M.: Summertime recirculations of air pollutants over the north-eastern lberian coast observed from systematic EARLINET lidar measurements in Barcelona, Atmos. Environ., 38, 3983-4000, 2004. 4968, 4971

Pérez, C., Nickovic, S., Baldasano, J. M., Sicard, M., Rocadenbosch, F., and Cachorro, V. E.: A long Saharan dust event over the western Mediterranean: Lidar, Sun photometer observations, and regional dust modeling, J. Geophys. Res., 111, D15214, doi:10.1029/2005JD006579, 2006a. 4960

Pérez, C., Nickovic, S., Pejanovic, G., Baldasano, J. M., and Ozsoy, E.: Interactive dustradiation modeling: A step to improve weather forecasts, J. Geophys. Res., 111, D16206, doi:10.1029/2005JD006717, 2006b. 4960

DAURE campaign meteorological overview

O. Jorba et al.

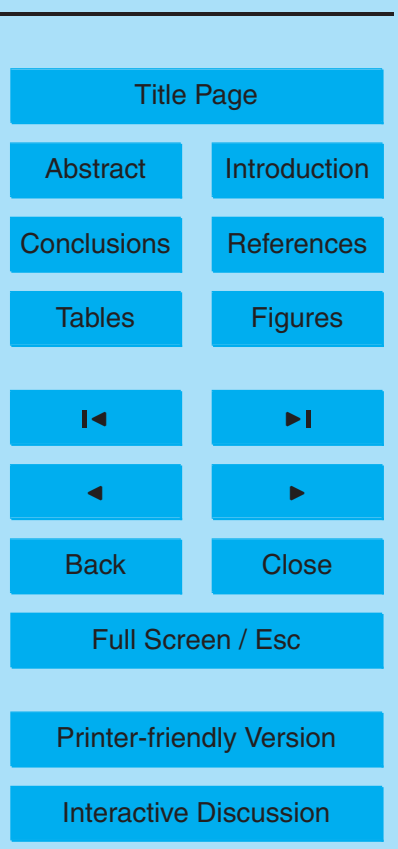


Perez, N., Pey, J., Castillo, S., Viana, M., Alastuey, A., and Querol, X.: Interpretation of the variability of levels of regional background aerosols in the Western Mediterranean, Sci. Total Environ., 407, 527-540, 2008a. 4956

Perez, N., Pey, J., Querol, X., Alastuey, A., Lopez, J. M., and Viana, M.: Partitioning of major and trace components in $\mathrm{PM}_{10}-\mathrm{PM}_{2.5}-\mathrm{PM}_{1}$ at an urban site in Southern Europe, Atmos. Environ., 42, 1677-1691, 2008b. 4956

Pey, J., Rodriguez, S., Querol, X., Alastuey, A., Moreno, T., Putaud, J. P., and van Dingenen, R.: Variations of urban aerosols in the western Mediterranean, Atmos. Environ., 42, 9052-9062, 2008. 4956

10 Pope, C. A. I., Ezzati, M., and Dockery, D. W.: Fine-Particulate Air Pollution and Life Expectancy in the United States, New Engl. J. Med., 360, 376-386, 2009. 4956

Querol, X., Alastuey, A., Puicercus, J., Mantilla, E., Miro, J., Lopez-Soler, A., Plana, F., and Nano, B. A.: Seasonal evolution of suspended particles around a large coal-fired power station: particulate levels and sources, Atmos. Environ., 32, 1963-1978, 1998a. 4956

Querol, X., Alastuey, A., Puicercus, J., Mantilla, E., Ruiz, C., Lopez-Soler, A., Plana, F., and Juan, R.: Seasonal evolution of suspended particles around a large coal-fired power station: chemical characterization, Atmos. Environ., 32, 719-731, 1998b. 4956

Querol, X., Alastuey, A., Rodríguez, S., Plana, F., Mantilla, E., and Ruiz, C.: Monitoring of PM $_{10}$ and $\mathrm{PM}_{2.5}$ around primary particulate anthropogenic emission sources, Atmos. Environ., 35(5), 845-858, 2001a. 4956

Querol, X., Alastuey, A., Rodríguez, S., Plana, F., Ruiz, C. R., Cots, N., Massagué, G., and Puig, O.: $\mathrm{PM}_{10}$ and $\mathrm{PM}_{2.5}$ source apportionment in the Barcelona Metropolitan Area, Catalonia, Spain, Atmos. Environ., 35(36), 6407-6419, 2001b. 4956

Rodríguez, S., Querol, X., Alastuey, A., Kallos, G., and Kakaliagou, O.: Saharan dust contributions to $\mathrm{PM}_{10}$ and TSP levels in Southern and Eastern Spain, Atmos. Environ., 35, 24332447, 2001. 4960

Rodríguez, S., Querol, X., Alastuey, A., and Mantilla, E.: Origin of high summer $\mathrm{PM}_{10}$ and TSP concentrations at rural sites in Eastern Spain, Atmos. Environ., 36, 3101-3112, 2002. 4960

Salvador, R., Millán, M., Mantilla, E., and Baldasano, J.: Mesoscale modelling of atmospheric processes over the western Mediterranean area during summer, Int. J. Environ. Pollut., 8, 513-529, 1997. 4971
ACPD

11, 4953-5001, 2011

\section{DAURE campaign \\ meteorological overview}

O. Jorba et al.

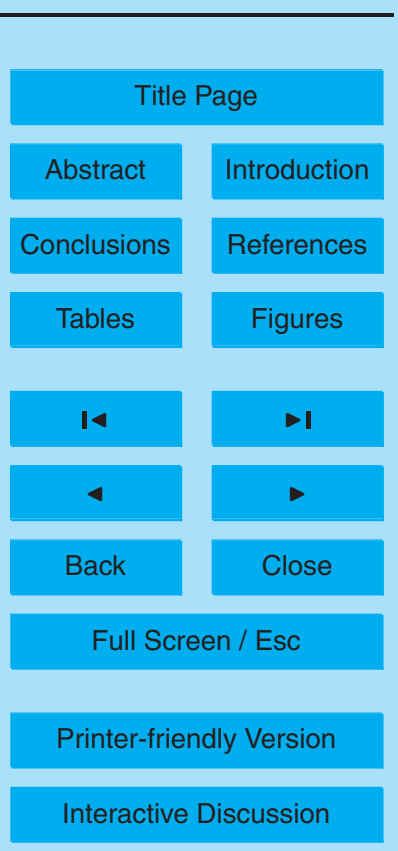


Sicard, M., Pérez, C., Rocadenbosch, F., Baldasano, J., and Garcia-Vizcaino, D.: Mixed layer depth determination in the Barcelona costal area from regular lidar measurements: methods, results and limitations, Bound.-Lay. Meteorol., 119, 135-157, 2006. 4959, 4967

Skamarock, W. C. and Klemp, J. B.: A time-split nonhydrostatic atmospheric model for 5 weather research and forecasting applications, J. Comput. Phys., 227(7), 3465-3485, doi:10.1016/j.jcp.2007.01.037, 2008. 4961

Soriano, C., Baldasano, J., Buttler, W., and Moore, K.: Circulatory patterns of air pollutants within the Barcelona air basin in a summertime situation: Lidar and numerical approaches, Bound.-Lay. Meteorol., 98, 33-55, 2001. 4971

Stohl, A., Hittenberger, M., and Wotawa, G.: Lagrangian particle dispersion model FLEXPART against large scale tracer experiment data, Atmos. Environ., 32, 4245-4264, 1998. 4961

Stohl, A., Eckhardt, S., Forster, C., James, P., Spichtinger, N., and Seibert, P.: A replacement for simple back trajectory calculations in the interpretation of atmospheric trace substance measurements, Atmos. Environ., 36, 4635-4648, 2002. 4961

Stull, R. B.: An Introduction to Boundary Layer Meteorology, Kluwer Academic Pub., Dordrecht/Boston/London, 1988. 4967

Szidat, S., Jenk, T. M., Synal, H.-A., Kalberer, M., Wacker, L., Hajdas, I., Kasper-Giebl, A., and Baltensperger, U.: Contributions of fossil fuel, biomass-burning, and biogenic emissions to carbonaceous aerosols in Zurich as traced by 14C, J. Geophys. Res., 111, D07206, doi:10.1029/2005JD006590, 2006. 4959

Viana, M., Pérez, C., Querol, X., Alastuey, A., Nickovic, S., and Baldasano, J. M.: Spatial and temporal variability of $\mathrm{PM}$ levels and composition in a complex summer atmospheric scenario in Barcelona (NE Spain), Atmos. Environ., 39, 5343-5361, 2005. 4956

Viana, M., Chi, X., Maenhaut, W., Querol, X., Alastuey, A., Mikuska, P., and Vecera, Z.: Organic and elemental carbon concentrations in carbonaceous aerosols during summer and winter sampling campaigns in Barcelona, Spain, Atmos. Environ., 40, 2180-2193, 2006. 4956

\section{ACPD}

$11,4953-5001,2011$

\section{DAURE campaign \\ meteorological overview}

O. Jorba et al.

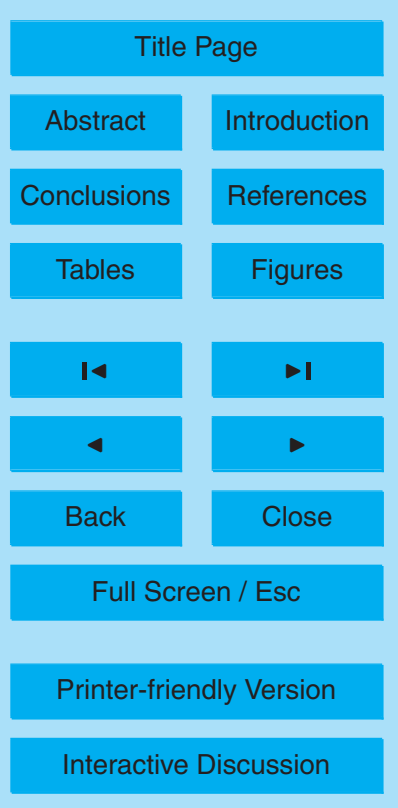


Table 1. Summary of surface meteorological conditions for the DAURE winter campaign (nocturnal temperature inversions are classified as $T 1, T 2, T 3, T 4^{*}$. Spatial averages of min. $T$, $\max . T, \mathrm{RH}$, solar irradiance, precipitation and sea level pressure are included).

\begin{tabular}{|c|c|c|c|c|c|c|c|c|c|}
\hline \multirow[b]{2}{*}{$\begin{array}{l}\text { Day } \\
\text { dd-mm-yyyy }\end{array}$} & \multicolumn{3}{|c|}{ Temperature inversion (00:00-06:00) } & \multicolumn{6}{|c|}{ Spatial averages } \\
\hline & $\begin{array}{c}\text { Montseny- } \\
\text { Valley }^{1} \\
(T 1, T 2, T 3, T 4)^{*}\end{array}$ & $\begin{array}{l}\text { Tibidabo-Valley }{ }^{2} \\
(T 1, T 2, T 3, T 4)^{\star}\end{array}$ & $\begin{array}{l}\text { Tibidabo-BCN } \\
(T 1, T 2, T 3, T 4)^{*}\end{array}$ & $\begin{array}{l}\text { Minimum } \\
\text { temperature }{ }^{4} \\
{ }^{\circ} \mathrm{C}\end{array}$ & $\begin{array}{l}\text { Maximum } \\
\text { temperature } \\
{ }^{\circ} \mathrm{C}\end{array}$ & $\begin{array}{c}\text { Relative } \\
\text { humidity } \\
\%\end{array}$ & $\begin{array}{r}\text { Solar irradiance } \\
\qquad \mathrm{MJ} \mathrm{m}^{-2}\end{array}$ & $\begin{array}{c}\text { Daily } \\
\text { precipitation } \\
\mathrm{mm}\end{array}$ & $\begin{array}{r}\text { Sea level } \\
\text { pressure } \\
\mathrm{hPa}\end{array}$ \\
\hline 24 Feb 2009 & & & & 5.4 & 13.9 & 75.3 & 10.4 & 0.0 & 1002.7 \\
\hline 25 Feb 2009 & & & & 4.0 & 16.6 & 71.2 & 16.1 & 0.0 & 1002.2 \\
\hline 26 Feb 2009 & & & & 5.4 & 18.8 & 60.2 & 16.4 & 0.0 & 995.7 \\
\hline $27 \mathrm{Feb} 2009$ & $T 2$ & $T 3$ & $T 2$ & 5.1 & 13.5 & 73.6 & 7.4 & 0.0 & 991.2 \\
\hline 28 Feb 2009 & $T 2$ & T4 & $T 2$ & 7.7 & 12.6 & 83.4 & 4.7 & 0.0 & 989.0 \\
\hline 1 Mar 2009 & & & & 6.1 & 13.3 & 83.2 & 6.9 & 0.1 & 993.7 \\
\hline 2 Mar 2009 & & & & 7.1 & 11.7 & 83.4 & 4.7 & 0.0 & 992.1 \\
\hline 3 Mar 2009 & & & & 4.5 & 10.9 & 83.4 & 5.9 & 0.1 & 973.1 \\
\hline 4 Mar 2009 & & & & 2.2 & 11.4 & 60.8 & 14.0 & 0.0 & 966.4 \\
\hline 5 Mar 2009 & & & & 2.9 & 15.3 & 43.7 & 18.5 & 0.0 & 976.5 \\
\hline 6 Mar 2009 & & & & 2.5 & 14.8 & 50.6 & 18.4 & 0.0 & 987.6 \\
\hline 7 Mar 2009 & $T 1$ & $T 3$ & & 5.5 & 16.9 & 67.4 & 18.4 & 0.0 & 993.1 \\
\hline 8 Mar 2009 & $T 1$ & $T 3$ & & 7.2 & 14.2 & 77.3 & 9.3 & 0.0 & 997.8 \\
\hline 9 Mar 2009 & & & & 8.4 & 17.4 & 68.9 & 17.5 & 0.0 & 998.5 \\
\hline 10 Mar 2009 & & & & 7.4 & 14.2 & 77.1 & 7.9 & 0.0 & 998.5 \\
\hline 11 Mar 2009 & & & & 6.0 & 16.4 & 77.4 & 16.3 & 0.0 & 1001.5 \\
\hline 12 Mar 2009 & & & & 7.9 & 21.8 & 62.7 & 18.7 & 0.0 & 997.6 \\
\hline 13 Mar 2009 & $T 2$ & $T 2$ & $T 1$ & 8.5 & 20.7 & 54.6 & 18.8 & 0.0 & 996.9 \\
\hline 14 Mar 2009 & $T 2$ & T4 & $T 3$ & 8.6 & 19.4 & 55.7 & 18.7 & 0.0 & 999.7 \\
\hline 15 Mar 2009 & $T 1$ & T4 & $T 2$ & 7.0 & 18.6 & 55.3 & 19.8 & 0.0 & 1001.4 \\
\hline 16 Mar 2009 & $T 2$ & T3 & & 6.5 & 18.2 & 53.2 & 20.0 & 0.0 & 1003.9 \\
\hline 17 Mar 2009 & $T 1$ & $\mathrm{~T} 4$ & & 6.2 & 19.1 & 57.2 & 19.6 & 0.0 & 999.8 \\
\hline 18 Mar 2009 & $T 1$ & $T 3$ & & 6.8 & 19.6 & 60.0 & 19.7 & 0.0 & 993.7 \\
\hline 19 Mar 2009 & $T 1$ & $T 3$ & & 5.9 & 17.0 & 59.6 & 20.0 & 0.0 & 994.1 \\
\hline 20 Mar 2009 & $T 1$ & T3 & & 4.9 & 13.9 & 62.1 & 15.7 & 0.0 & 997.8 \\
\hline 21 Mar 2009 & & & & 4.1 & 16.5 & 64.8 & 20.3 & 0.0 & 1000.3 \\
\hline 22 Mar 2009 & & & & 6.3 & 21.2 & 51.3 & 21.5 & 0.0 & 996.6 \\
\hline 23 Mar 2009 & $T 1$ & $T 3$ & & 6.3 & 18.6 & 56.6 & 18.7 & 0.0 & 990.1 \\
\hline 24 Mar 2009 & $T 1$ & $T 3$ & $T 2$ & 5.1 & 17.5 & 53.8 & 21.6 & 0.0 & 991.8 \\
\hline 25 Mar 2009 & & & & 6.2 & 16.4 & 68.6 & 16.8 & 0.0 & 992.2 \\
\hline 26 Mar 2009 & & $T 3$ & & 6.6 & 18.7 & 69.2 & 21.4 & 0.0 & 987.8 \\
\hline 27 Mar 2009 & $T 1$ & T4 & $T 1$ & 7.8 & 12.4 & 85.8 & 2.8 & 0.5 & 978.4 \\
\hline 28 Mar 2009 & & & & 7.2 & 14.4 & 80.8 & 11.2 & 0.2 & 980.3 \\
\hline 29 Mar 2009 & & & & 7.6 & 13.2 & 76.6 & 8.7 & 0.0 & 989.2 \\
\hline 30 Mar 2009 & & & & 7.3 & 11.0 & 83.0 & 3.5 & 0.8 & 988.3 \\
\hline
\end{tabular}

${ }^{*} T 1, T 2, T 3$, and $T 4$ stand for: $T 1=\Delta T / \Delta Z<0.005 \mathrm{Km}^{-1} ; T 2=0.005<\Delta T / \Delta Z<0.01 \mathrm{Km}^{-1} ; T 3=0.01 \mathrm{Km}^{-1}<\Delta T / \Delta Z<0.02 \mathrm{Km}{ }^{-1} ; T 4=\Delta T / \Delta Z>$ $0.02 \mathrm{Km}^{-1}$;

${ }^{1}$ Mean computed with stations VX, X9, XG, WE; ${ }^{2}$ Mean computed with stations D5, VT; ${ }^{3}$ Mean computed with stations D5, X2, X4; ${ }^{4}$ Mean computed with stations VX, X9, XG, WE, VT, X2, X4; ${ }^{5}$ Mean computed with stations $\mathrm{X} 9, \mathrm{XG}, \mathrm{D} 5, \mathrm{X} 4$

\section{ACPD}

11, 4953-5001, 2011

\section{DAURE campaign meteorological overview}

O. Jorba et al.

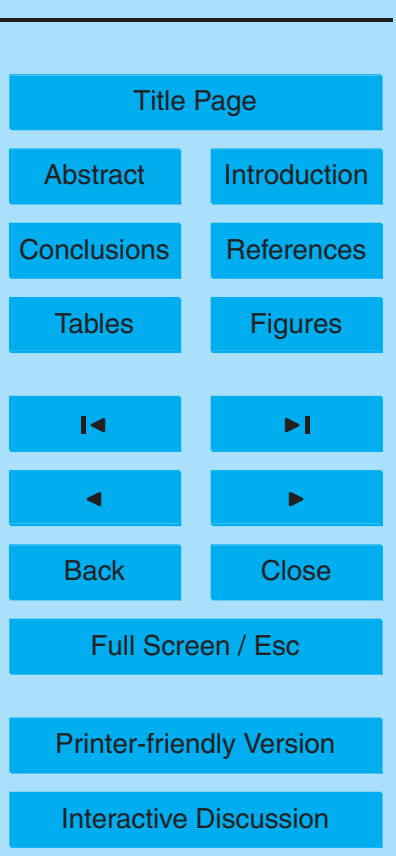

Interactive Discussion 
Table 2. Summary of aloft meteorological conditions and situation types for the DAURE winter campaign.

\begin{tabular}{|c|c|c|c|c|c|c|c|c|c|}
\hline dd-mm-yyyy & $\begin{array}{c}\text { Cloud cover } \\
\text { MODIS } \\
(12: 00 \text { UTC) } \\
(S, P, C)^{*}\end{array}$ & $\begin{array}{l}\text { Cloud height and type } \\
\text { METAR } \\
(12: 00 \text { UTC) } \\
(\mathrm{Sc}, \mathrm{Bk}, \mathrm{Fw}, \mathrm{FwCb}, \mathrm{Nsc})^{\star *}\end{array}$ & $\begin{array}{l}\text { Visibility } \\
\text { METAR } \\
\text { 12:00 UTC } \\
\mathrm{m}\end{array}$ & $\begin{array}{r}\text { Sfc. wind Dir. } \\
\text { BCN sounding } \\
12: 00 \text { UTC } \\
\text { at } 98 \text { ma.g.l. }\end{array}$ & $\begin{array}{l}\text { Sfc. wind Spd. } \\
\text { BCN sounding } \\
\text { 12:00 UTC } \\
\mathrm{m} \mathrm{s}^{-1} \text { at } 98 \mathrm{~m} \text { a.g.l. }\end{array}$ & $\begin{array}{r}\text { Synoptic wind Dir. } \\
\text { BCN sounding } \\
12: 00 \text { UTC } \\
{ }^{\circ} \text { at } 850 \mathrm{hPa}\end{array}$ & $\begin{array}{r}\text { Synoptic wind Spd. } \\
\text { BCN sounding } \\
12: 00 \text { UTC } \\
\mathrm{m} \mathrm{s}^{-1} \text { at } 850 \mathrm{hPa}\end{array}$ & $\begin{array}{r}\text { PBL height } \\
\text { BCN sounding } \\
12: 00 \text { UTC } \\
\mathrm{m}\end{array}$ & Situation type ${ }^{1}$ \\
\hline 24 Feb 2009 & $\mathrm{~s}$ & - & - & 210 & 1.0 & 165 & 1.6 & 1080 & A \\
\hline 25 Feb 2009 & C & - & - & 142 & 1.0 & 340 & 3.3 & 1051 & C \\
\hline 26 Feb 2009 & $\mathrm{~s}$ & - & _- & 238 & 1.5 & 297 & 2.2 & 855 & $\mathrm{~F}$ \\
\hline 27 Feb 2009 & $\mathrm{~s}$ & - & - & 126 & 2.5 & 133 & 4.4 & 555 & $A-D$ \\
\hline 28 Feb 2009 & $\mathrm{c}$ & - & - & 143 & 1.0 & 162 & 6.9 & 678 & $E-D$ \\
\hline 1 Mar 2009 & c & $\mathrm{Sc}(457 \mathrm{~m}) \mathrm{Bk}(1371 \mathrm{~m})$ & 8000 & 275 & 1.5 & 254 & 7.1 & 818 & $\mathrm{pC}$ \\
\hline 2 Mar 2009 & $\mathrm{c}$ & Sc $(762 \mathrm{~m}) \mathrm{Sc}(1706 \mathrm{~m})$ & 8000 & 264 & 0.5 & 227 & 1.4 & 974 & $\mathrm{pC}$ \\
\hline 3 Mar 2009 & $\mathrm{c}$ & Sc $(670 \mathrm{~m})$ & 8000 & 270 & 1.0 & 322 & 1.2 & 1300 & $\mathrm{pC}$ \\
\hline 4 Mar 2009 & c & Fw (457 m) Sc (914 m) & 10000 or more & 232 & 1.5 & 261 & 15.4 & 1100 & $\mathrm{pC}$ \\
\hline 5 Mar 2009 & $\mathrm{c}$ & $\mathrm{Sc}(487 \mathrm{~m}) \mathrm{Bk}(1219 \mathrm{~m})$ & 10000 or more & 277 & 7.2 & 301 & 22.2 & 1190 & $\mathrm{C}$ \\
\hline 6 Mar 2009 & $\mathrm{~s}$ & $\mathrm{Fw}(670 \mathrm{~m})$ & 10000 or more & 285 & 4.5 & 301 & 5.8 & 1402 & c \\
\hline 7 Mar 2009 & $\mathrm{~s}$ & $\mathrm{Fw}(914 \mathrm{~m})$ & 10000 or more & 100 & 2.0 & 350 & 5.1 & 600 & $\mathrm{c}$ \\
\hline 8 Mar 2009 & s & $\mathrm{Fw}(609 \mathrm{~m})$ & 10000 or more & 120 & 5.0 & 308 & 6.2 & 1017 & A \\
\hline 9 Mar 2009 & c & $\mathrm{FW}(609 \mathrm{~m}) \mathrm{Bk}(1371 \mathrm{~m})$ & 10000 or more & 84 & 1.5 & 0 & 0.3 & 1456 & A \\
\hline 10 Mar 2009 & $\mathrm{~s}$ & $\mathrm{FW}(548 \mathrm{~m})$ & 10000 or more & 226 & 2.5 & 307 & 11.6 & 1380 & $\hat{\mathrm{F}}$ \\
\hline 11 Mar 2009 & $\mathrm{c}$ & Sc $(457 \mathrm{~m}) \mathrm{Bk}(1158 \mathrm{~m})$ & 10000 or more & 91 & 2.5 & 304 & 10.3 & 1190 & A \\
\hline 12 Mar 2009 & $\mathrm{P}$ & $\mathrm{FW}(548 \mathrm{~m})$ & 10000 or more & 244 & 1.0 & 308 & 4.1 & 1156 & A \\
\hline 13 Mar 2009 & s & $\mathrm{Fw}(609 \mathrm{~m})$ & 9000 & 268 & 1.0 & 283 & 6.1 & 378 & $\mathrm{~F}-\mathrm{D}$ \\
\hline 14 Mar 2009 & $\mathrm{~s}$ & Nsc & 7000 & 66 & 5.0 & 178 & 2.8 & 504 & $B-D$ \\
\hline 15 Mar 2009 & $\mathrm{~s}$ & Nsc & 10000 or more & 260 & 1.0 & 262 & 8.5 & 1105 & A-D \\
\hline 16 Mar 2009 & $\mathrm{~s}$ & Nsc & 10000 or more & 81 & 6.0 & 72 & 8.9 & 1380 & $C-D$ \\
\hline 17 Mar 2009 & $\mathrm{~s}$ & Nsc & 10000 or more & 115 & 3.3 & 46 & 2.6 & 1012 & D \\
\hline 18 Mar 2009 & $\mathrm{~s}$ & Nsc & 10000 or more & 240 & 1.0 & 9 & 0.8 & 1068 & D \\
\hline 19 Mar 2009 & $\mathrm{~s}$ & Nsc & 10000 or more & 229 & 5.0 & 315 & 2.2 & 569 & $F-D$ \\
\hline 20 Mar 2009 & $\mathrm{~s}$ & Nsc & 10000 or more & 179 & 1.3 & 348 & 12.3 & 839 & $\mathrm{C}$ \\
\hline 21 Mar 2009 & $\mathrm{c}$ & $\mathrm{Sc}(700 \mathrm{~m})$ & 10000 or more & 227 & 2.5 & 309 & 7.8 & 1780 & A \\
\hline 22 Mar 2009 & $\mathrm{~s}$ & Fw $(762 \mathrm{~m})$ & 10.000 or more & 200 & 3.0 & 356 & 5.9 & 1260 & $\mathrm{~F}$ \\
\hline 23 Mar 2009 & s & Nsc & 10000 or more & 289 & $\begin{array}{l}3.0 \\
1.0\end{array}$ & 321 & 1.9 & 870 & $F-D$ \\
\hline 24 Mar 2009 & $\mathrm{c}$ & Sc (518m) & 8000 & 349 & 3.0 & 318 & 6.1 & 1089 & $F-D$ \\
\hline 25 Mar 2009 & $\mathrm{~s}$ & $\mathrm{Fw}(762 \mathrm{~m})$ & 10000 or more & 251 & 2.5 & 278 & 8.8 & 1650 & $\mathrm{~F}$ \\
\hline 26 Mar 2009 & $\mathrm{c}$ & Fw $(609 \mathrm{~m})$ & 10000 or more & 130 & 4.1 & 289 & 6.9 & 1229 & B \\
\hline 27 Mar 2009 & $\mathrm{~s}$ & $\mathrm{Fw}(518 \mathrm{~m})$ & 10000 or more & 190 & 1.0 & 268 & 6.4 & 507 & F-D \\
\hline 28 Mar 2009 & $\mathrm{c}$ & $\mathrm{Fw}(457 \mathrm{~m}) \mathrm{Sc}(1066 \mathrm{~m})$ & 10000 or more & 45 & $\begin{array}{l}3.0 \\
3.0\end{array}$ & $\begin{array}{l}200 \\
166\end{array}$ & $\begin{array}{l}0.4 \\
4.3\end{array}$ & 408 & $E$ \\
\hline 29 Mar 2009 & $\mathrm{c}$ & $\mathrm{FW}(457 \mathrm{~m}) \mathrm{Bk}(1219 \mathrm{~m})$ & 10000 or more & 250 & 2.0 & 348 & 3.4 & 1049 & $\mathrm{~F}$ \\
\hline 30 Mar 2009 & $\mathrm{c}$ & $\mathrm{Sc}(762 \mathrm{~m}) \mathrm{Sc}(1371 \mathrm{~m})$ & 10000 or more & 127 & 1.0 & 295 & $\begin{array}{l}3.4 \\
3.2\end{array}$ & 848 & A \\
\hline
\end{tabular}

${ }^{*} \mathrm{~S}, \mathrm{P}, \mathrm{C}$ stand for: S: clear sky; P: partially covered; C: covered

** Sc, Bk, Fw, FwCb, Nsc stand for: Sc: scattered; Bk: broken sky; Fw: a few; FwCb: a few cumulonimbus; Nsc: no significant clouds below 5000 feet; ( m): estimated cloud height

${ }^{1}$ Classification from FLEXPART-WRF cluster-backtrajectories. A: stagnant conditions with daily SW sea-breeze development; B: stagnant conditions with daily SE sea-breeze development; pC: previous days to northern advection; C: northern advection; D: strong nocturnal thermal inversion; E: southern advections; F: westerly-northwesterly advections.
ACPD

11, 4953-5001, 2011

\section{DAURE campaign meteorological overview}

O. Jorba et al.

Title Page

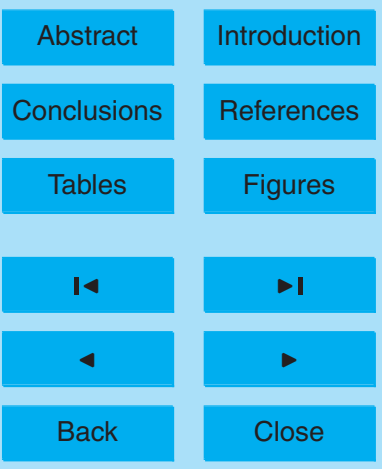

Full Screen / Esc

Printer-friendly Version

Interactive Discussion 
Table 3. Summary of surface meteorological conditions for the DAURE summer campaign (nocturnal temperature inversions are classified as $T 1, T 2, T 3, T 4^{*}$. Spatial averages of min. $T$, max. $T, \mathrm{RH}$, solar irradiance, precipitation and sea level pressure are included).

\begin{tabular}{|c|c|c|c|c|c|c|c|c|c|}
\hline \multirow[b]{2}{*}{ Day } & \multicolumn{3}{|c|}{ Temperature inversion (00:00-06:00) } & \multicolumn{6}{|c|}{ Spatial averages } \\
\hline & $\begin{array}{l}\text { Montseny- } \\
\text { Valley }^{1}\end{array}$ & Tibidabo-Valley² & Tibidabo-BCN ${ }^{3}$ & $\begin{array}{l}\text { Minimum } \\
\text { temperature }\end{array}$ & $\begin{array}{l}\text { Maximum } \\
\text { temperature }\end{array}$ & $\begin{array}{c}\text { Relative } \\
\text { humidity }^{4}\end{array}$ & Solar irradiance $^{4}$ & $\begin{array}{c}\text { Daily } \\
\text { precipitation }\end{array}$ & $\begin{array}{l}\text { Sea level } \\
\text { pressure }^{5}\end{array}$ \\
\hline dd-mm-yyyy & $(T 1, T 2, T 3, T 4)^{*}$ & $(T 1, T 2, T 3, T 4)^{*}$ & $(T 1, T 2, T 3, T 4)^{*}$ & ${ }^{\circ} \mathrm{C}$ & ${ }^{\circ} \mathrm{C}$ & $\%$ & $\mathrm{MJ} \mathrm{m}^{-2}$ & & $\mathrm{hPa}$ \\
\hline 1 Jul 2009 & T3 & T3 & $T 2$ & 20.9 & 32.1 & 45.7 & 26.8 & 0.0 & 994.7 \\
\hline 2 Jul 2009 & T3 & T3 & $T 1$ & 20.6 & 32.2 & 49.3 & 25.7 & 0.0 & 993.4 \\
\hline 3 Jul 2009 & & & & 19.9 & 31.0 & 54.8 & 27.3 & 0.0 & 991.6 \\
\hline 4 Jul 2009 & & $T 2$ & & 20.8 & 31.0 & 53.9 & 28.8 & 0.0 & 988.9 \\
\hline 5 Jul 2009 & & & & 20.1 & 30.0 & 60.9 & 27.2 & 0.1 & 988.4 \\
\hline 6 Jul 2009 & & & & 20.1 & 28.7 & 62.7 & 22.6 & 0.0 & 989.1 \\
\hline 7 Jul 2009 & & & & 19.7 & 24.6 & 68.4 & 12.0 & 0.1 & 990.5 \\
\hline 8 Jul 2009 & & & & 17.9 & 22.1 & 68.9 & 7.1 & 0.0 & 994.3 \\
\hline 9 Jul 2009 & & & & 16.9 & 20.4 & 83.9 & 4.6 & 0.6 & 995.6 \\
\hline 10 Jul 2009 & & & & 17.7 & 23.4 & 75.7 & 14.1 & 0.0 & 995.5 \\
\hline 11 Jul 2009 & & & & 17.7 & 23.5 & 75.0 & 10.9 & 0.0 & 994.8 \\
\hline 12 Jul 2009 & & & & 19.4 & 28.7 & 74.6 & 26.0 & 0.0 & 992.0 \\
\hline 13 Jul 2009 & & $T 2$ & & 19.6 & 30.0 & 61.3 & 28.5 & 0.0 & 990.4 \\
\hline 14 Jul 2009 & $T 1$ & & & 20.6 & 29.0 & 69.7 & 24.7 & 0.0 & 988.9 \\
\hline 15 Jul 2009 & & & & 20.5 & 28.4 & 69.5 & 25.7 & 0.0 & 994.6 \\
\hline 16 Jul 2009 & $T 1$ & $T 2$ & & 20.3 & 29.2 & 70.1 & 26.0 & 0.0 & 995.5 \\
\hline 17 Jul 2009 & & & & 19.5 & 26.2 & 72.6 & 19.1 & 0.0 & 1047.1 \\
\hline 18 Jul 2009 & & & & 14.8 & 25.6 & 44.2 & 29.6 & 0.0 & 997.6 \\
\hline 19 Jul 2009 & & & & 15.2 & 26.5 & 60.9 & 27.0 & 0.0 & 998.2 \\
\hline 20 Jul 2009 & & & & 18.0 & 29.5 & 59.4 & 27.5 & 0.0 & 997.2 \\
\hline 21 Jul 2009 & $T 1$ & & & 19.0 & 29.2 & 57.5 & 26.9 & 0.0 & 994.1 \\
\hline 22 Jul 2009 & & & & 20.3 & 30.7 & 66.9 & 23.8 & 0.1 & 989.2 \\
\hline 23 Jul 2009 & & T3 & & 21.7 & 36.0 & 45.9 & 27.2 & 0.0 & 987.6 \\
\hline 24 Jul 2009 & & & & 21.3 & 33.5 & 48.3 & 27.8 & 0.0 & 993.4 \\
\hline 25 Jul 2009 & & & & 19.2 & 27.6 & 64.7 & 25.4 & 0.0 & 999.4 \\
\hline 26 Jul 2009 & & & & 19.1 & 29.2 & 65.0 & 27.0 & 0.0 & 996.5 \\
\hline 27 Jul 2009 & & & & 19.8 & 30.2 & 62.4 & 23.2 & 0.0 & 993.0 \\
\hline 28 Jul 2009 & & & & 19.8 & 28.5 & 61.6 & 26.0 & 0.0 & 995.2 \\
\hline 29 Jul 2009 & $T 1$ & $T 2$ & & 19.6 & 30.2 & 65.0 & 26.6 & 0.0 & 994.1 \\
\hline 30 Jul 2009 & & & & 21.7 & 30.4 & 68.8 & 25.9 & 0.0 & 997.2 \\
\hline 31 Jul 2009 & & & & 20.4 & 29.7 & 64.7 & 25.8 & 0.0 & 995.4 \\
\hline
\end{tabular}

${ }^{*} T 1, T 2, T 3$, and $T 4$ stand for: $T 1=\Delta T / \Delta Z<0.005 \mathrm{Km}^{-1} ; T 2=0.005<\Delta T / \Delta Z<0.01 \mathrm{Km}^{-1} ; T 3=0.01 \mathrm{Km}^{-1}<\delta T / \delta Z<0.02 \mathrm{Km}^{-1} ; T 4=\Delta T / \Delta Z>$ $0.02 \mathrm{Km}^{-1}$

${ }^{1}$ Mean computed with stations VX, X9, XG, WE; ${ }^{2}$ Mean computed with stations D5, VT; ${ }^{3}$ Mean computed with stations D5, X2, X4; ${ }^{4}$ Mean computed with stations VX, X9, XG, WE, VT, X2, X4; ${ }^{5}$ Mean computed with stations $\mathrm{X} 9, \mathrm{XG}, \mathrm{D} 5, \mathrm{X} 4$

ACPD

11, 4953-5001, 2011

\section{DAURE campaign meteorological overview}

O. Jorba et al.

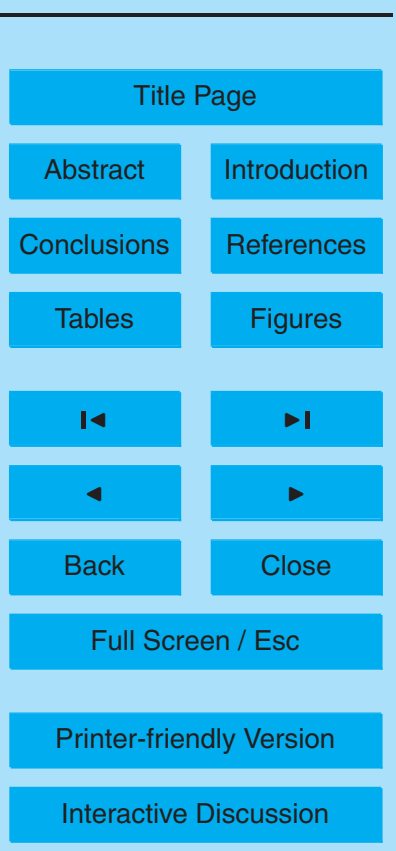




\section{ACPD}

11, 4953-5001, 2011

Table 4. Summary of aloft meteorological conditions and situation types for the DAURE summer campaign.

\begin{tabular}{|c|c|c|c|c|c|c|c|c|c|}
\hline dd-mm-yyyy & $\begin{array}{c}\text { Cloud cover } \\
\text { MODIS } \\
(12: 00 \text { UTC) } \\
(\mathrm{S}, \mathrm{P}, \mathrm{C})^{*}\end{array}$ & $\begin{array}{l}\text { Cloud height and type } \\
\text { METAR } \\
(12: 00 \text { UTC) } \\
(\mathrm{Sc}, \mathrm{Bk}, \mathrm{Fw}, \mathrm{FwCb}, \mathrm{Nsc})^{* *}\end{array}$ & $\begin{array}{l}\text { Visibility } \\
\text { METAR } \\
\text { (12:00 UTC) } \\
m\end{array}$ & $\begin{array}{l}\text { Sfc. wind Dir. } \\
\text { BCN sounding } \\
\text { (12:00 UTC) } \\
\text { 'at } 98 \text { m a.g.l. }\end{array}$ & $\begin{array}{c}\text { Sfc. wind Spd. } \\
\text { BCN sounding } \\
\text { (12:00 UTC) } \\
\mathrm{m} \mathrm{s}^{-1} \text { at } 98 \mathrm{~m} \text { a.g.l. }\end{array}$ & $\begin{array}{c}\text { Synoptic wind Dir. } \\
\text { BCN sounding } \\
\text { (12:00 UTC) } \\
{ }^{\circ} \text { at } 850 \mathrm{hPa}\end{array}$ & $\begin{array}{r}\text { Synoptic wind Spd. } \\
\text { BCN sounding } \\
\text { (12:00 UTC) } \\
\mathrm{m} \mathrm{s}^{-1} \text { at } 850 \mathrm{hPa}\end{array}$ & $\begin{array}{r}\text { PBL height } \\
\text { BCN sounding } \\
\text { (12:00 UTC) } \\
\mathrm{m}\end{array}$ & Situation type ${ }^{1}$ \\
\hline 1 Jul 2009 & $\mathrm{C}$ & Fw $(609 \mathrm{~m})$ & 10000 or more & 121 & 5.3 & 230 & 5.5 & 788 & A \\
\hline 2 Jul 2009 & C & $\mathrm{Fw}(762 \mathrm{~m})$ & 10000 or more & 166 & 1.5 & 164 & 4.3 & 692 & A \\
\hline 3 Jul 2009 & $\mathrm{~s}$ & Fw (670 m) & 10000 or more & 203 & 1.5 & 226 & 4.6 & 1108 & A \\
\hline 4 Jul 2009 & $\mathrm{P}$ & $\mathrm{FwCb}(762 \mathrm{~m})$ & 10000 or more & 110 & 3.0 & 194 & 4.4 & 1230 & A \\
\hline 5 Jul 2009 & C & $\mathrm{Sc}(762 \mathrm{~m})$ & 10000 or more & 190 & 2.0 & 176 & 1.3 & 1590 & A \\
\hline 6 Jul 2009 & C & Fw (762 m) & 10000 or more & 153 & 3.0 & 235 & 5.5 & 1444 & A \\
\hline 7 Jul 2009 & c & $\mathrm{Sc}(548 \mathrm{~m}) \mathrm{Sc}(1280 \mathrm{~m})$ & 10000 or more & 129 & 3.5 & 228 & 5.7 & 878 & A \\
\hline 8 Jul 2009 & c & Fw (762 m) Bk (1676 m) & 10000 or more & 12 & 1.0 & 235 & 4.4 & 1079 & B \\
\hline 9 Jul 2009 & C & $\mathrm{Fw}(518 \mathrm{~m}) \mathrm{Sc}(762 \mathrm{~m}) \mathrm{Bk}(1068 \mathrm{~m})$ & 4000 & 336 & 1.5 & 274 & 3.6 & - & B \\
\hline 10 Jul 2009 & C & $\mathrm{Bk}(1005 \mathrm{~m})$ & 10000 or more & 138 & 2.0 & 262 & 5.9 & 1010 & B \\
\hline 11 Jul 2009 & C & $\mathrm{Bk}(670 \mathrm{~m})$ & 10000 or more & 160 & 1.0 & 241 & 8.4 & 840 & B \\
\hline 12 Jul 2009 & $\mathrm{P}$ & $\mathrm{Sc}(762 \mathrm{~m})$ & 10000 or more & 220 & 3.0 & 251 & 7.8 & 840 & A \\
\hline 13 Jul 2009 & $\mathrm{~s}$ & $\mathrm{Fw}(426 \mathrm{~m})$ & 10000 or more & 110 & 3.2 & 191 & 9.1 & 582 & A \\
\hline 14 Jul 2009 & c & $\mathrm{Fw}(670 \mathrm{~m})$ & 10000 or more & 97 & 4.5 & 196 & 2.5 & 601 & $\mathrm{E}$ \\
\hline 15 Jul 2009 & c & $\mathrm{Sc}(1066 \mathrm{~m})$ & 10000 or more & 146 & 2.5 & 258 & 4.5 & 1230 & B-E \\
\hline 16 Jul 2009 & $\mathrm{P}$ & Fw $(762 \mathrm{~m})$ & 10000 or more & 113 & 1.4 & 194 & 5.7 & 580 & E \\
\hline 17 Jul 2009 & C & $\mathrm{Sc}(670 \mathrm{~m}) \mathrm{Sc}(914 \mathrm{~m})$ & 10.000 or more & 163 & 2.8 & 280 & 8.4 & 900 & C \\
\hline 18 Jul 2009 & $\mathrm{~s}$ & Nsc & 10000 or more & 210 & 2.0 & 313 & 7.0 & 1940 & D \\
\hline 19 Jul 2009 & $\mathrm{P}$ & $\mathrm{Fw}(609 \mathrm{~m})$ & 10000 or more & 165 & 2.0 & 305 & 10.7 & 1321 & A \\
\hline 20 Jul 2009 & $\mathrm{P}$ & Nsc & 10000 or more & 216 & 2.8 & 245 & 10.3 & 956 & $\mathrm{E}$ \\
\hline 21 Jul 2009 & $\mathrm{~s}$ & Fw (518 m) & 10000 or more & 180 & 2.0 & 215 & 7.1 & 865 & E \\
\hline 22 Jul 2009 & $\mathrm{P}$ & Fw $(609 \mathrm{~m})$ & 10000 or more & 240 & 2.0 & 227 & 12.9 & 1150 & E \\
\hline 23 Jul 2009 & s & $\mathrm{Fw}(609 \mathrm{~m})$ & 10000 or more & 277 & 4.7 & 253 & 14.5 & 1650 & $\mathrm{E}$ \\
\hline 24 Jul 2009 & s & Nsc & 10000 or more & 170 & 2.0 & 247 & 12.0 & 990 & A \\
\hline 25 Jul 2009 & $\mathrm{~s}$ & $\mathrm{Fw}(914 \mathrm{~m})$ & 10000 or more & 208 & 2.3 & 297 & 10.9 & 1170 & A \\
\hline 26 Jul 2009 & $\mathrm{~s}$ & $\mathrm{Fw}(670 \mathrm{~m})$ & 10000 or more & 190 & 2.0 & 246 & 9.1 & 960 & A \\
\hline 27 Jul 2009 & $\mathrm{P}$ & $\mathrm{Fw}(762 \mathrm{~m})$ & 10000 or more & 223 & 2.0 & 235 & 9.3 & 1020 & \\
\hline 28 Jul 2009 & $\mathrm{~s}$ & Nsc & 10000 or more & 138 & 4.0 & 302 & 3.6 & 960 & $A-E$ \\
\hline 29 Jul 2009 & $\mathrm{~s}$ & Nsc & 10000 or more & 226 & 1.0 & 266 & 9.6 & 920 & $A-E$ \\
\hline 30 Jul 2009 & $\mathrm{~s}$ & $\mathrm{Fw}(609 \mathrm{~m})$ & 10000 or more & 196 & 3.0 & 214 & 4.2 & 1200 & $A-E$ \\
\hline 31 Jul 2009 & $\mathrm{P}$ & $\mathrm{Fw}(762 \mathrm{~m})$ & 10000 or more & 218 & 3.0 & 237 & 6.7 & 1009 & \\
\hline
\end{tabular}

\section{DAURE campaign meteorological overview}

O. Jorba et al.

Title Page

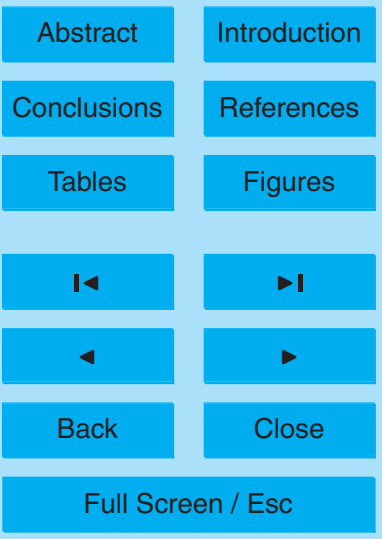

m): estimated cloud height

${ }^{1}$ Classification from FLEXPART-WRF cluster-backtrajectories. A: See-breeze regime; B: thunderstorm event; C: E-NE advection coupled with the see-breeze regime; D: weak W advection; E: SW advection coupled with long-range transport of Saharan Dust.

Printer-friendly Version

Interactive Discussion 


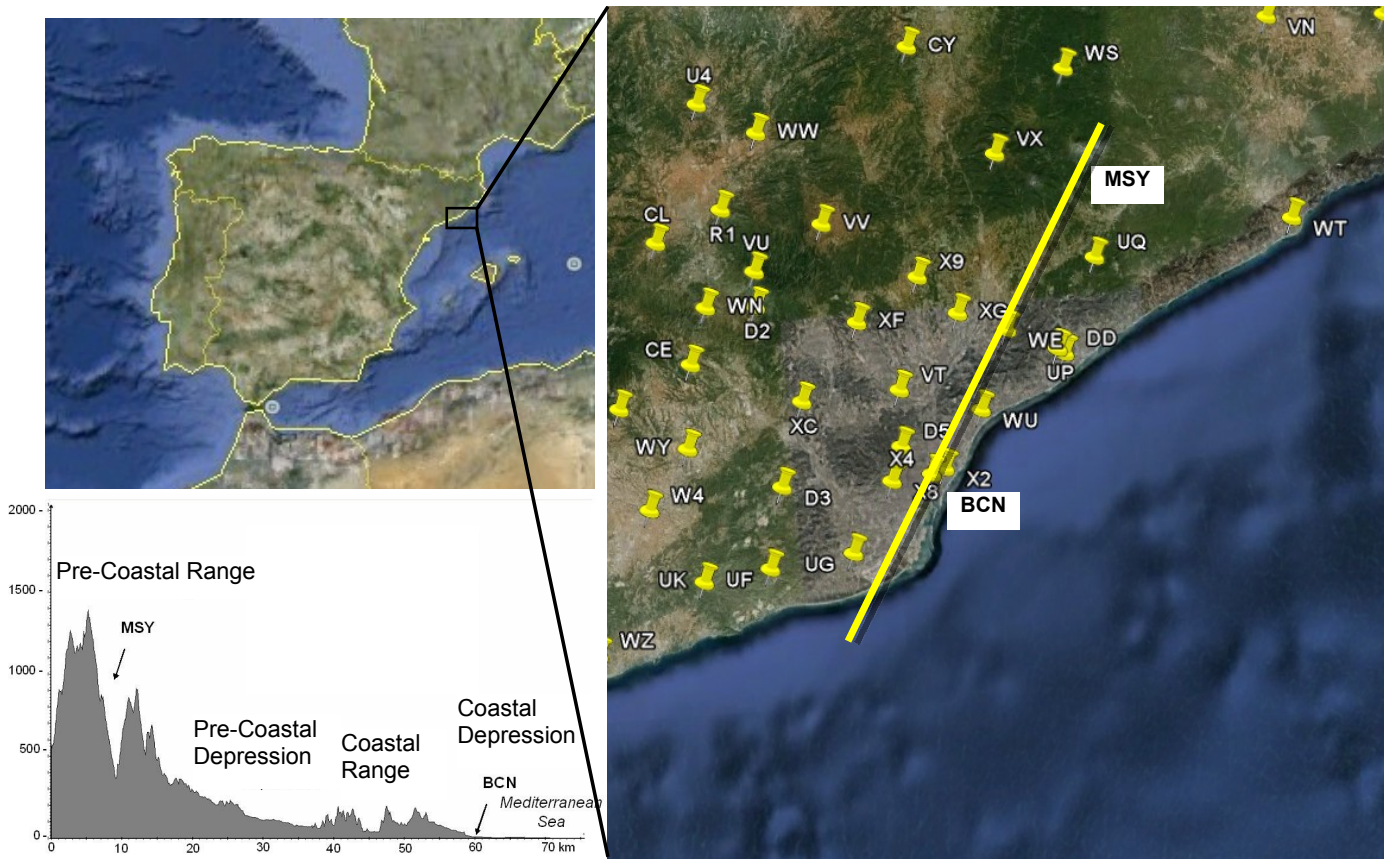

Fig. 1. Left: Barcelona geographical area and cross section of the topography between $B C N$ and MSY sites. Right: Meteorological surface observations available in the area of study (yellow points: meteorological stations located between BCN and MSY sites).

\section{ACPD}

$11,4953-5001,2011$

DAURE campaign meteorological overview

O. Jorba et al.

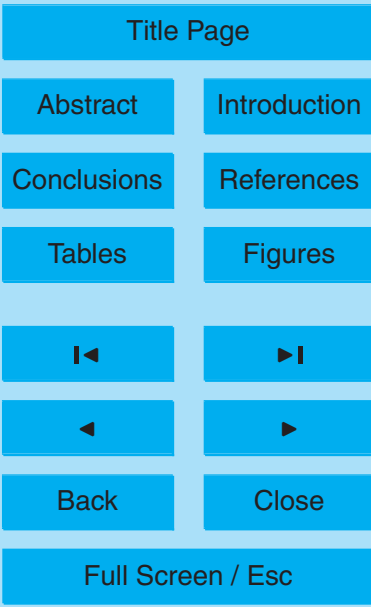

Printer-friendly Version

Interactive Discussion 

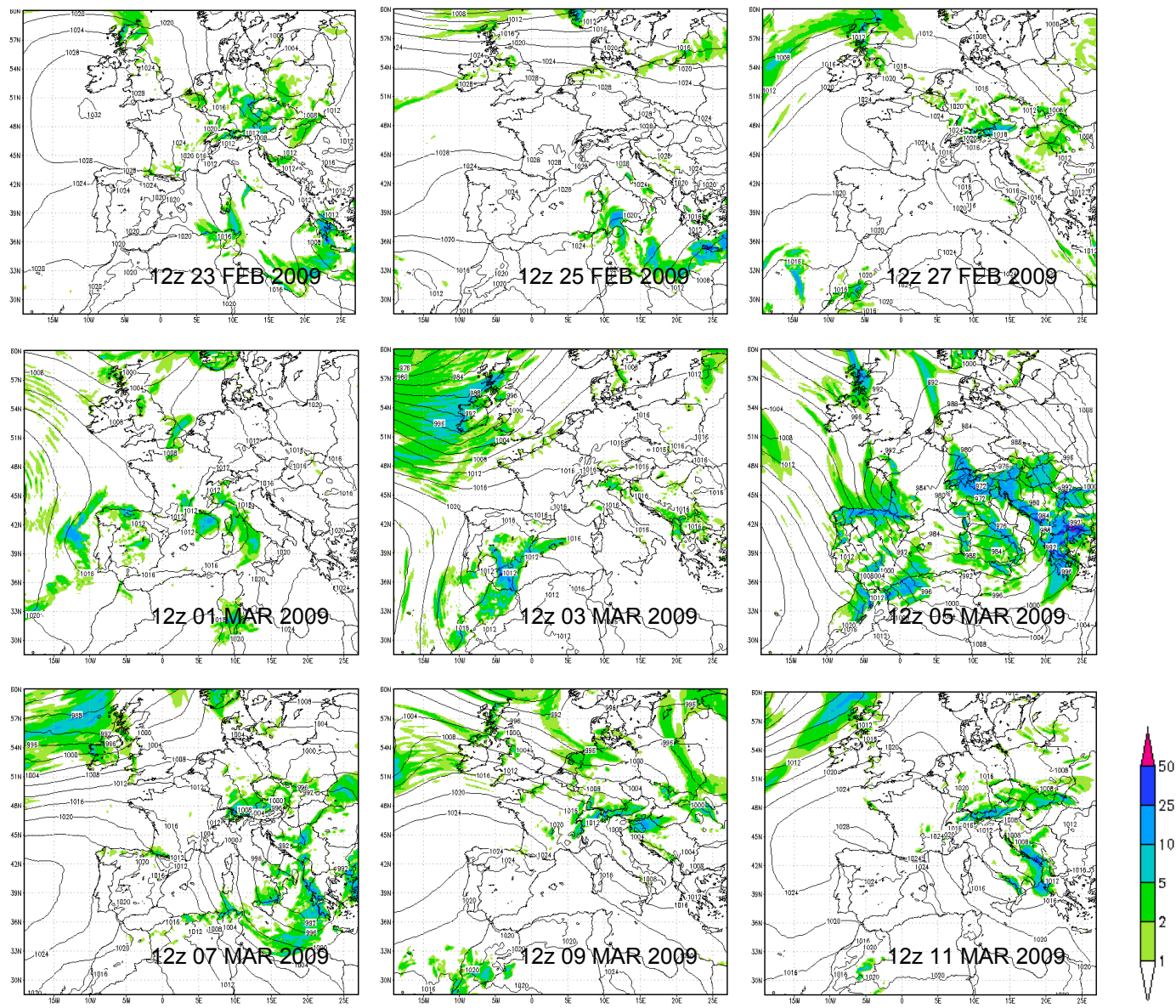

Fig. 2a. See caption on next page.
ACPD

11, 4953-5001, 2011

DAURE campaign meteorological overview

O. Jorba et al.

Title Page

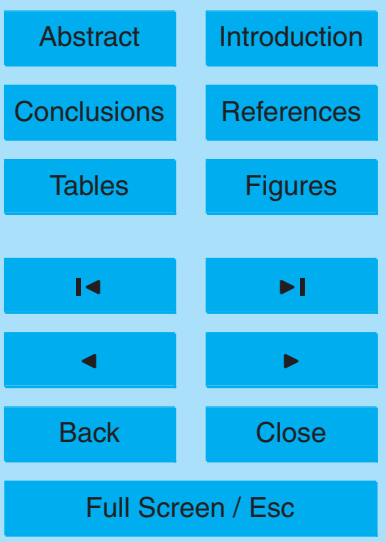

Printer-friendly Version

Interactive Discussion 

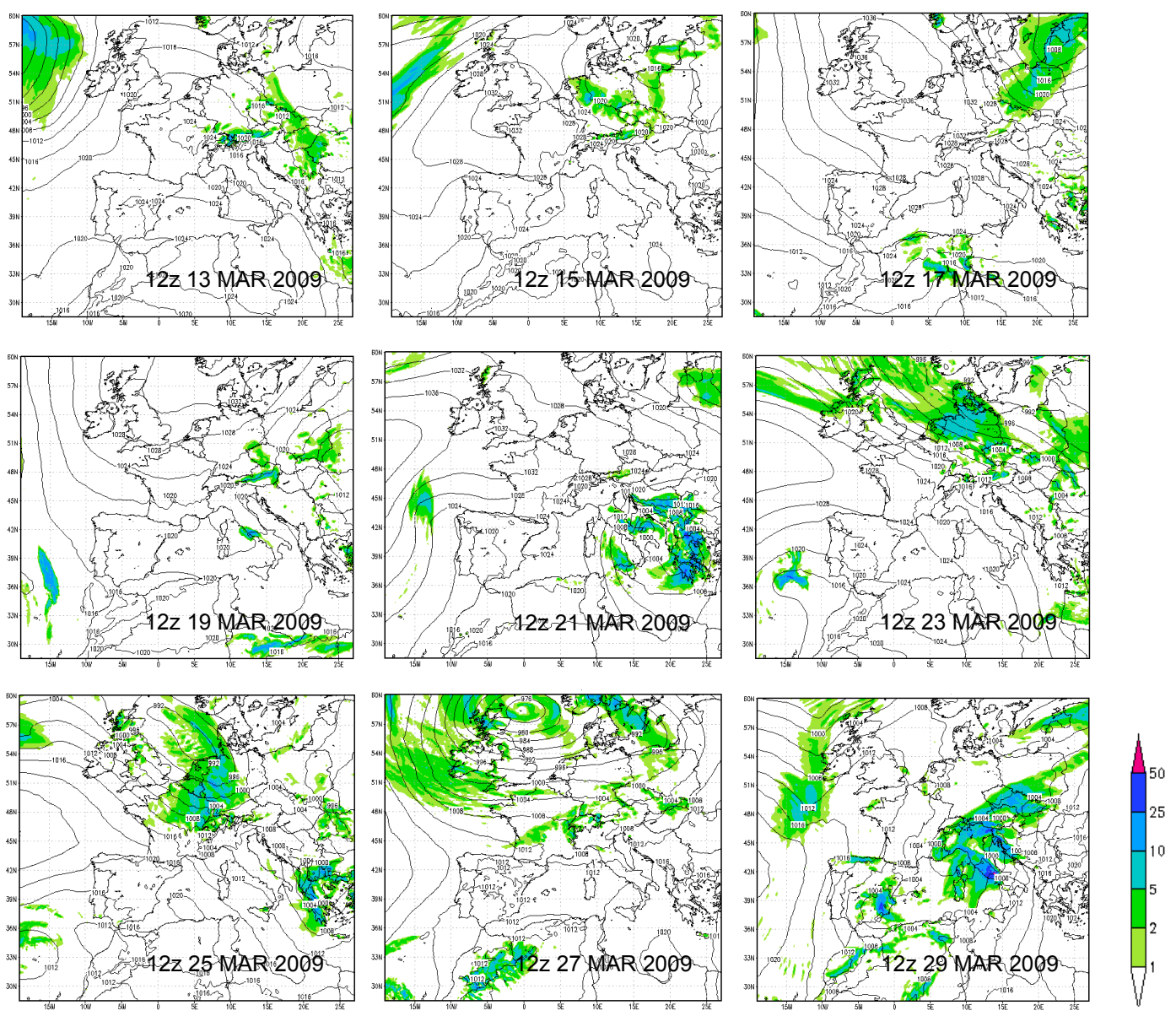

Fig. 2b. Synoptic evolution during the DAURE winter campaign, sea level pressure and 6-h accumulated precipitation.
ACPD

11, 4953-5001, 2011

DAURE campaign meteorological overview

O. Jorba et al.

Title Page

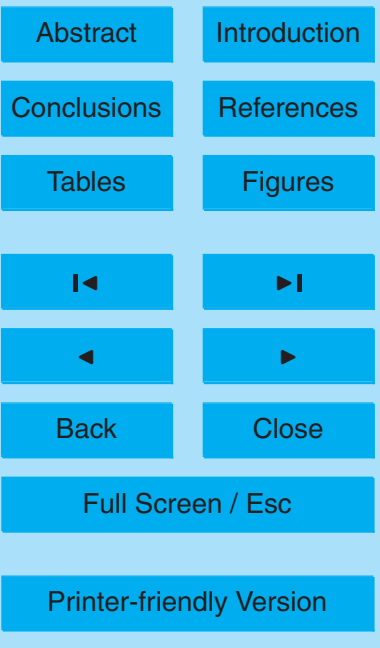

Interactive Discussion 
ACPD

11, 4953-5001, 2011

Meteorological Station X8-Barcelona_University
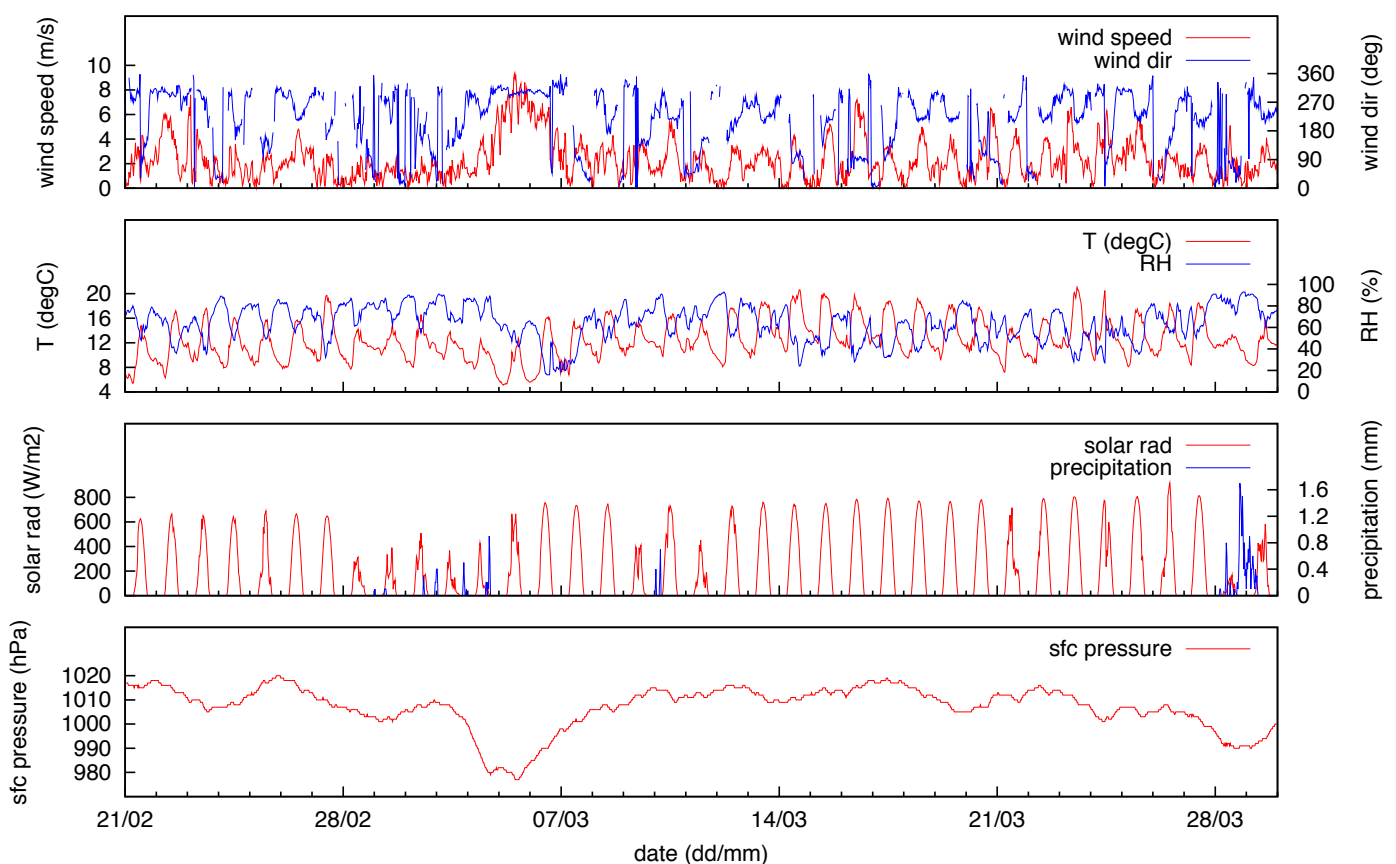

Fig. 3. Meteogram of $\mathrm{BCN}$ site for the winter campaign (wind direction is plotted when wind speed is higher than $0.5 \mathrm{~m} \mathrm{~s}^{-1}$; measurements every $30 \mathrm{~min}$ ).

DAURE campaign meteorological overview

O. Jorba et al.

Title Page

Abstract

Introduction

Conclusions

References

Tables

Figures

14

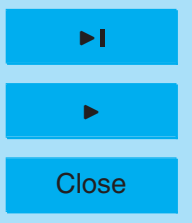

Back

\section{Full Screen / Esc}

Printer-friendly Version

Interactive Discussion

(c) (1) 


\section{ACPD}

11, 4953-5001, 2011

\section{DAURE campaign meteorological overview}
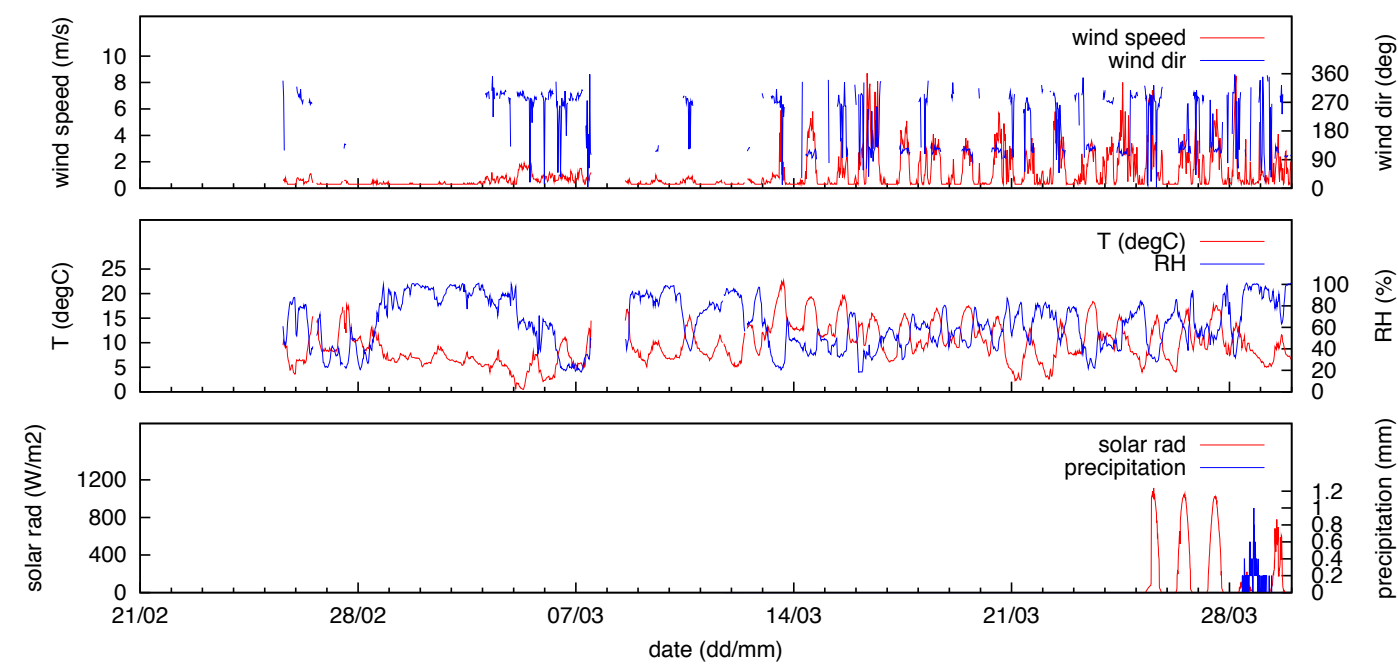

Fig. 4. Meteogram of MSY site for the winter campaign (wind direction is plotted when wind speed is higher than $0.5 \mathrm{~m} \mathrm{~s}^{-1}$; measurements every $10 \mathrm{~min}$ ). 

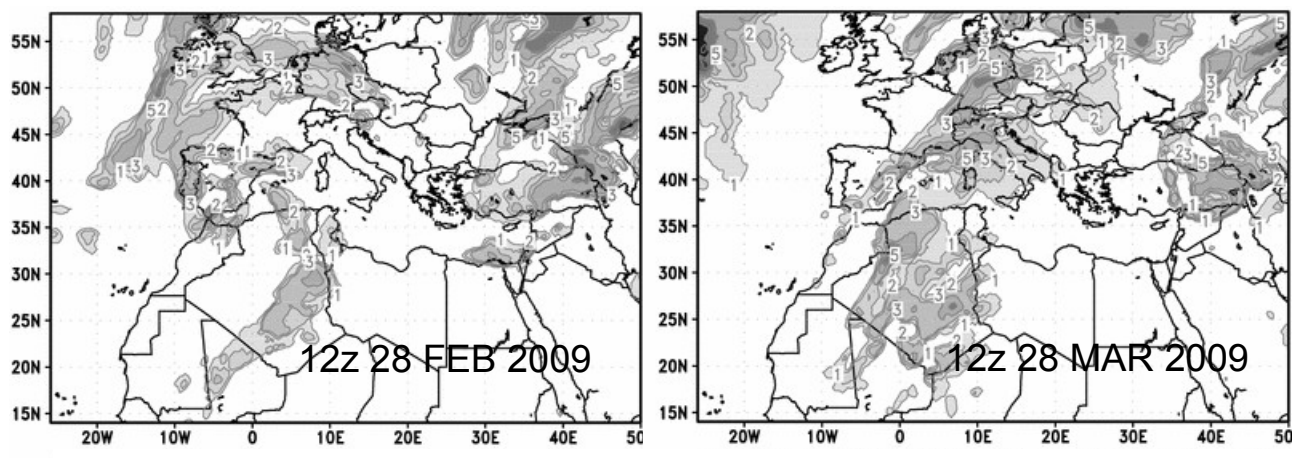

\section{ACPD}

$11,4953-5001,2011$

DAURE campaign meteorological overview

O. Jorba et al.
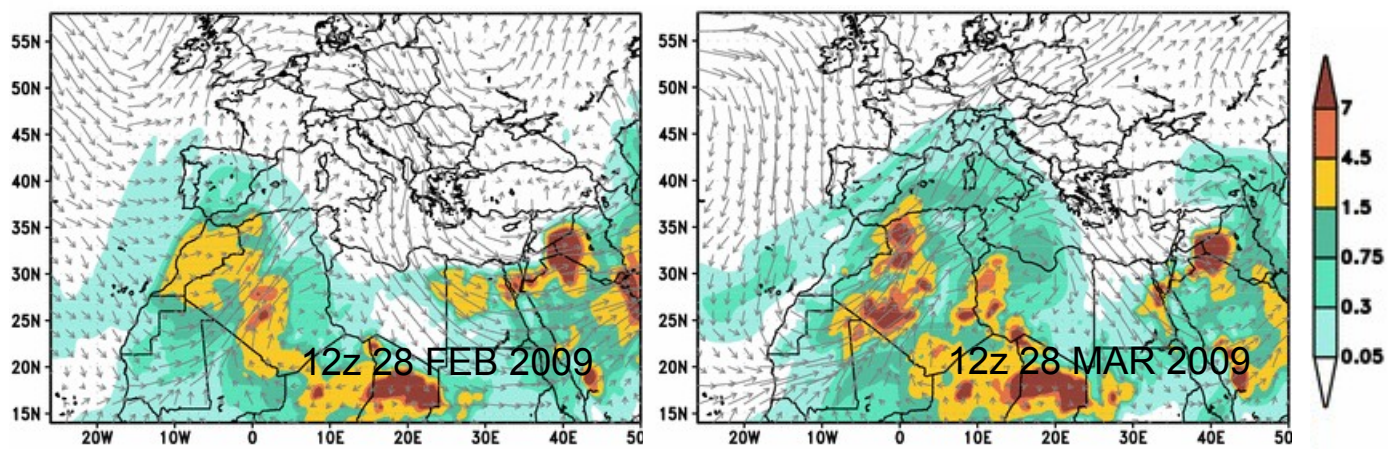

Fig. 5. Two Saharan dust outbreaks over the Iberian peninsula during the DARUE winter campaign (top: BSC-DREAM8b total cloud cover; bottom: BSC-DREAM8b dust loading in $\mathrm{g} \mathrm{m}^{-2}$ and $3000 \mathrm{~m}$ wind field).

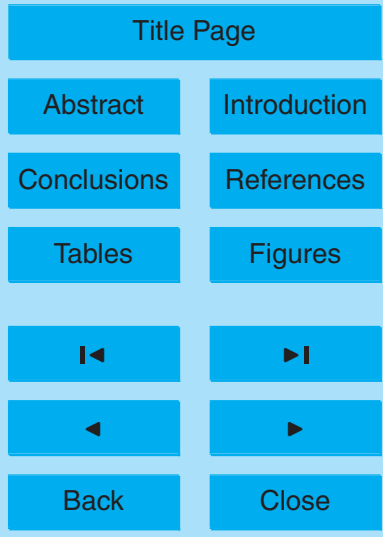

Full Screen / Esc

Printer-friendly Version

Interactive Discussion

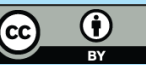




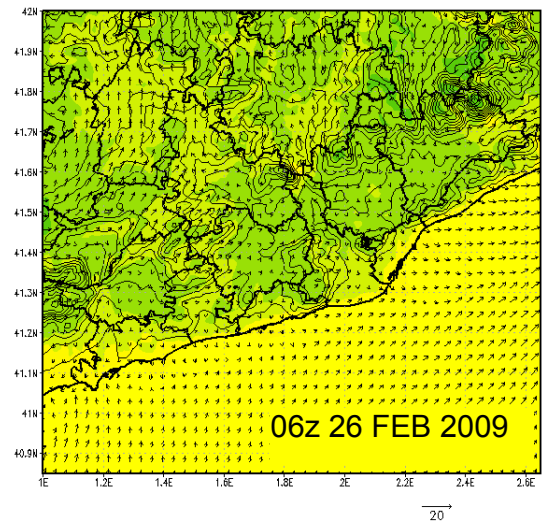

(a)

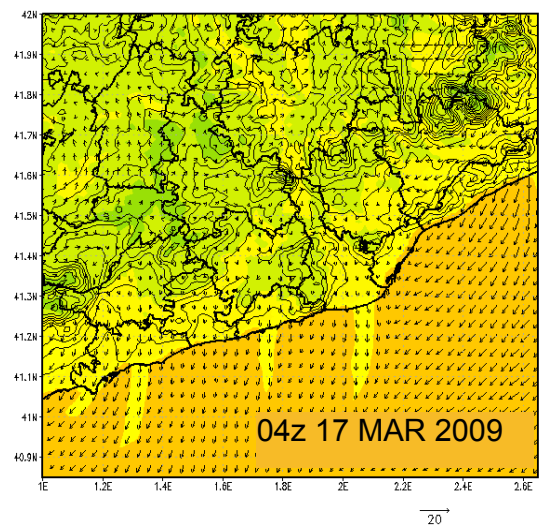

(c)

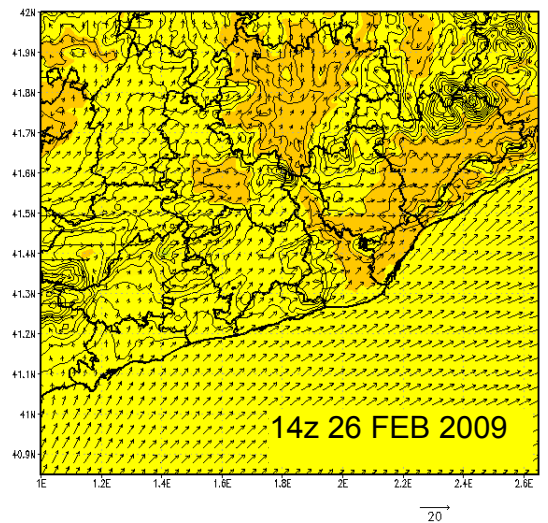

(b)

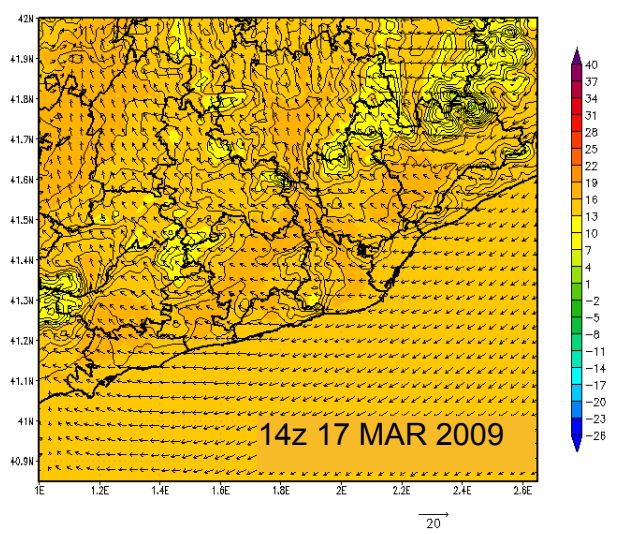

(d)

Fig. 6. Surface wind field and $2 \mathrm{~m}$ air Temperature for (a) 06:00 UTC and (b) 14:00 UTC 26 February and (c) 04:00 UTC and (d) 14:00 UTC 17 March 2009 (color map: $2 \mathrm{~m}$ air temperature; vector map: $10 \mathrm{~m}$ surface wind field).

\section{ACPD}

$11,4953-5001,2011$

\section{DAURE campaign meteorological overview}

O. Jorba et al.

Title Page

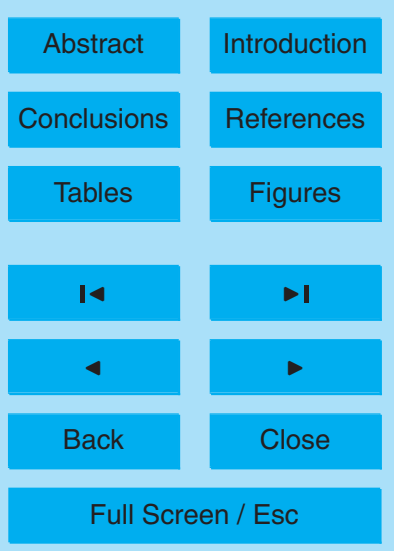

Printer-friendly Version

Interactive Discussion 


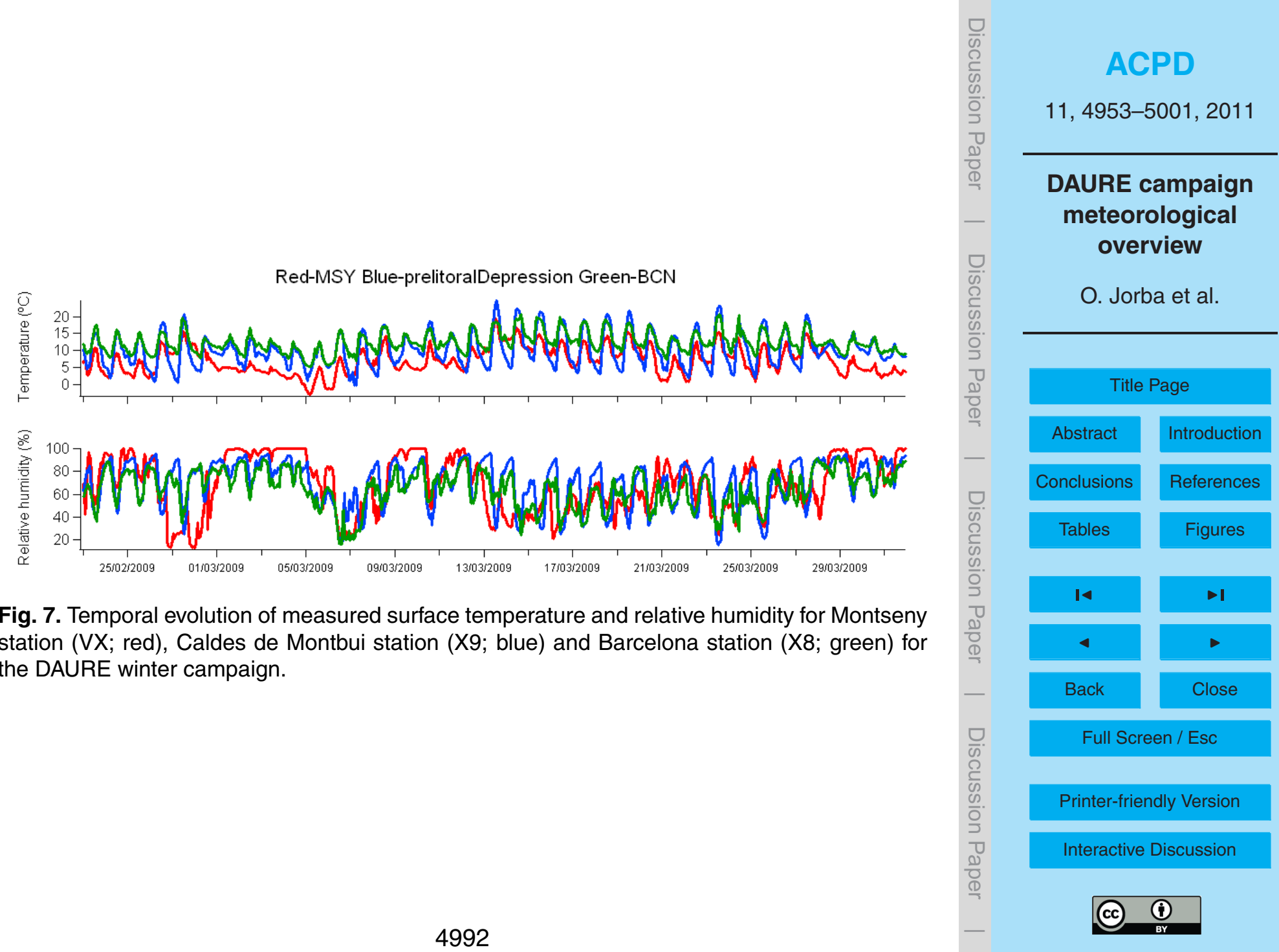




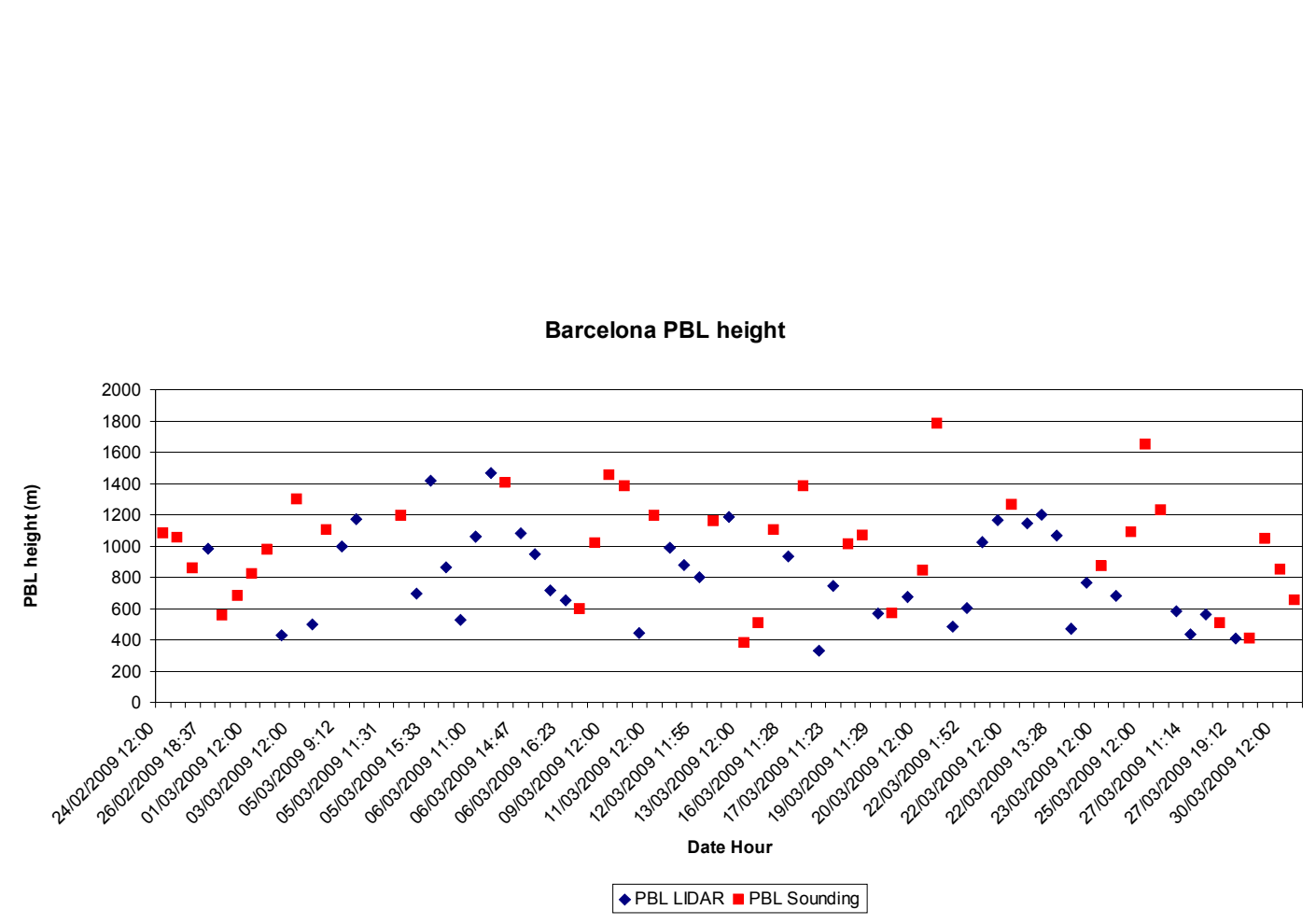

Fig. 8. PBL height during the DAURE winter campaign retrived from radiosoundings and LIDAR profiles at $B C N$ site.

\section{ACPD}

11, 4953-5001, 2011

DAURE campaign meteorological overview

O. Jorba et al.

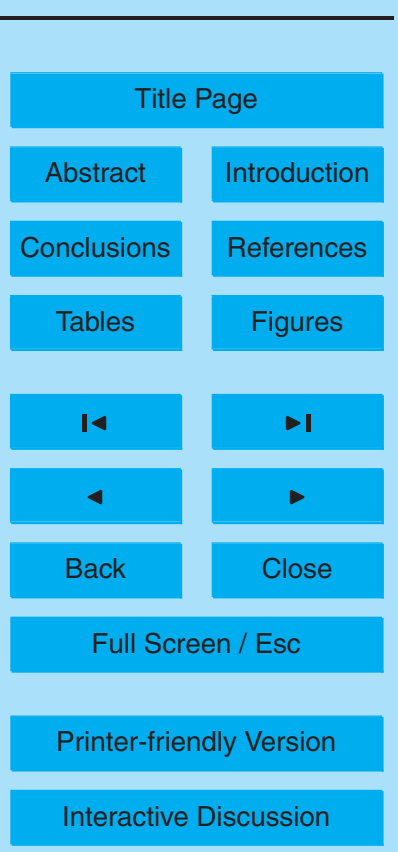




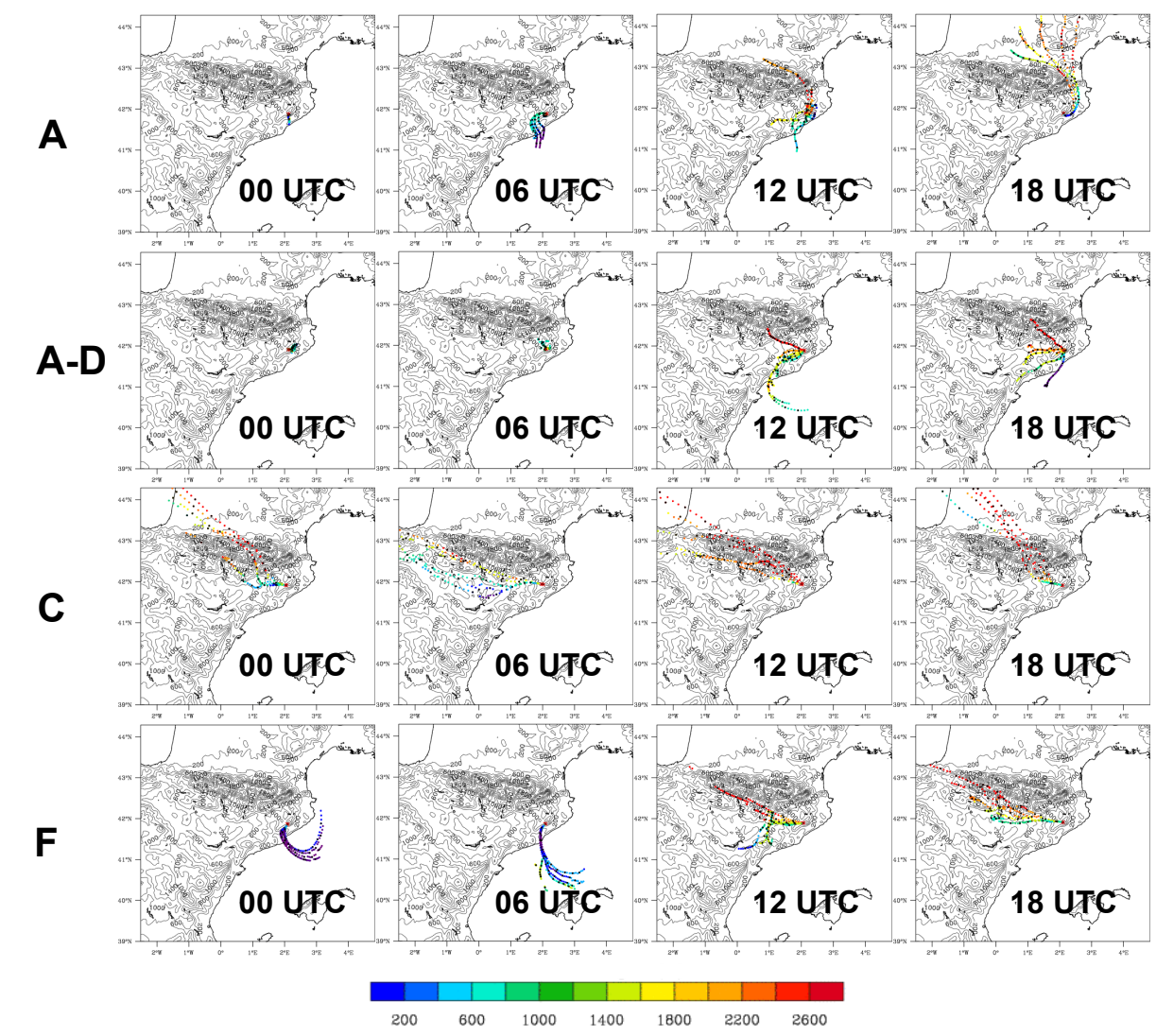

Fig. 9. Cluster-backtrajectories for typical situations of winter campaign. Trajectories are colored according to the altitude of the air mass in ma.g.l. (black points every hour). A: 24 February 2009 stagnant conditions with daily SW sea-breeze development; A-D: 15 March 2009 situation type A with strong nocturnal thermal inversion; C: 5 March 2009 northern advection; F: 10 March 2009 western-northwestern advection.

\section{ACPD}

11, 4953-5001, 2011

DAURE campaign meteorological overview

O. Jorba et al.

\section{Title Page}

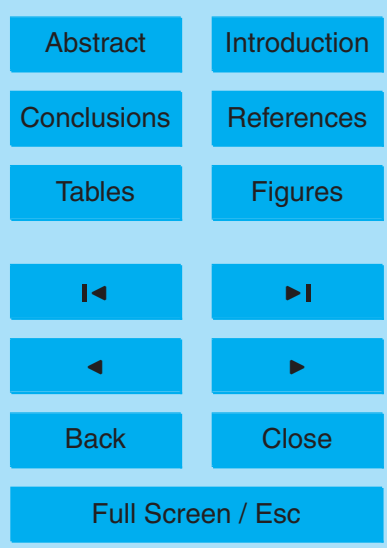

Printer-friendly Version

Interactive Discussion 

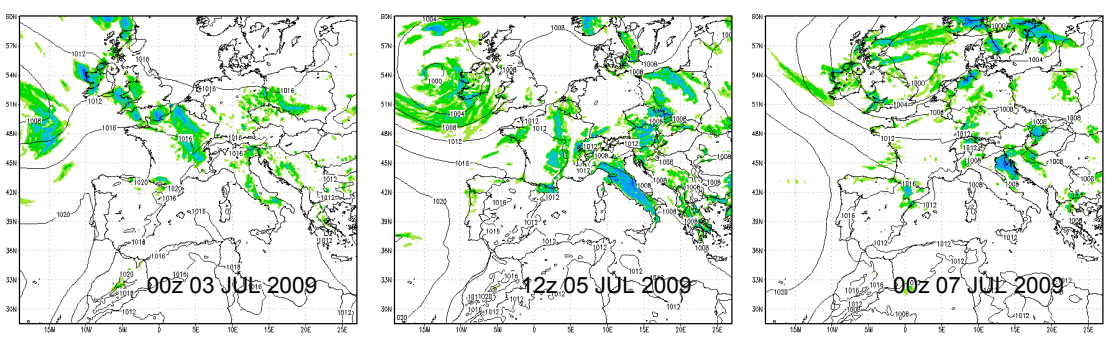

ACPD

11, 4953-5001, 2011
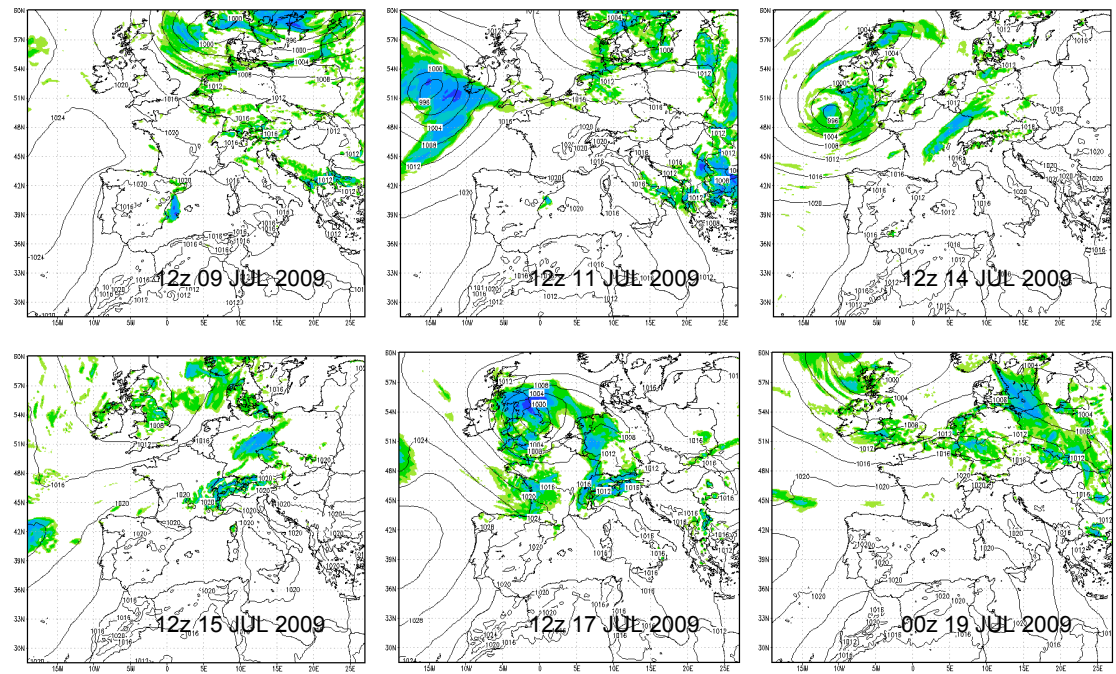

\section{DAURE campaign meteorological overview}

O. Jorba et al.

Title Page

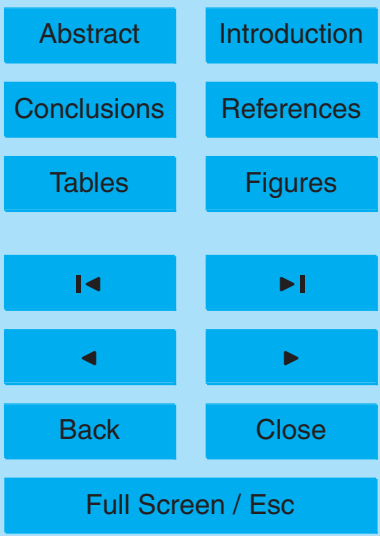

Printer-friendly Version

Fig. 10a. See caption on next page.

Interactive Discussion 


\section{ACPD}

11, 4953-5001, 2011
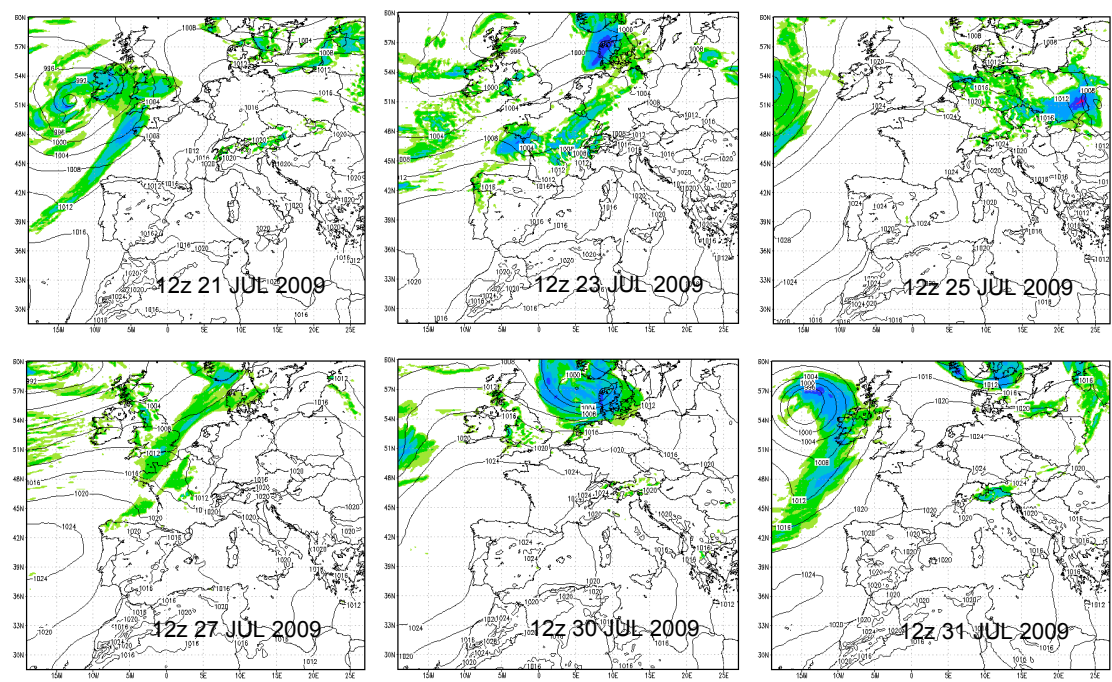

\section{DAURE campaign meteorological overview}

O. Jorba et al.

Fig. 10b. Synoptic evolution during the DAURE summer campaign, sea level pressure and 6-h accumulated precipitation.

Title Page

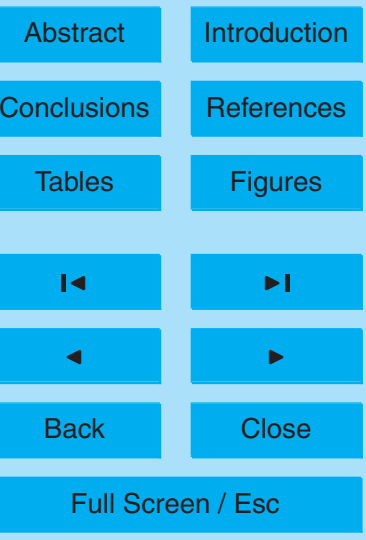

Printer-friendly Version

Interactive Discussion 

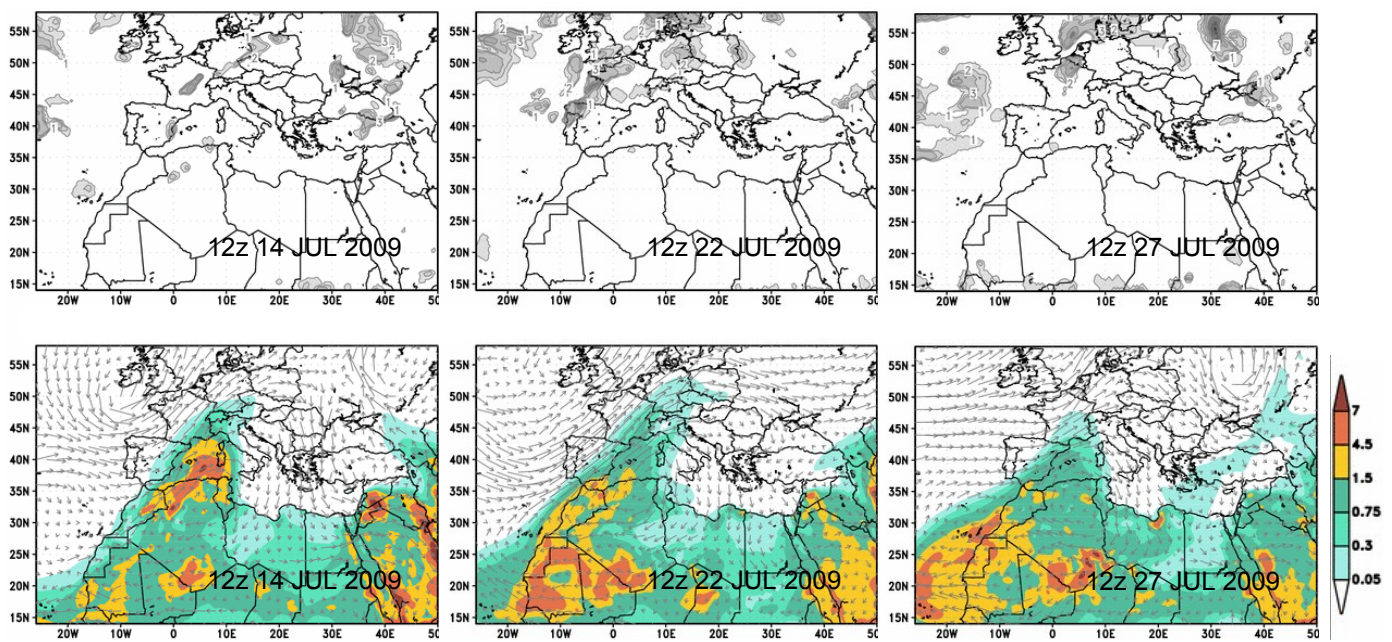

Fig. 11. Three Saharan dust outbreaks over the Iberian peninsula during the DARUE summer campaign (top: BSC-DREAM8b total cloud cover; bottom: BSC-DREAM8b dust loading in $\mathrm{g} \mathrm{m}^{-2}$ and $3000 \mathrm{~m}$ wind field).

DAURE campaign meteorological overview

O. Jorba et al.

Title Page

Abstract Introduction

Conclusions References

Tables

Figures

14

4

Back

Close

Full Screen / Esc

Printer-friendly Version

Interactive Discussion 


\section{ACPD}

11, 4953-5001, 2011

Meteorological Station X8-Barcelona_University
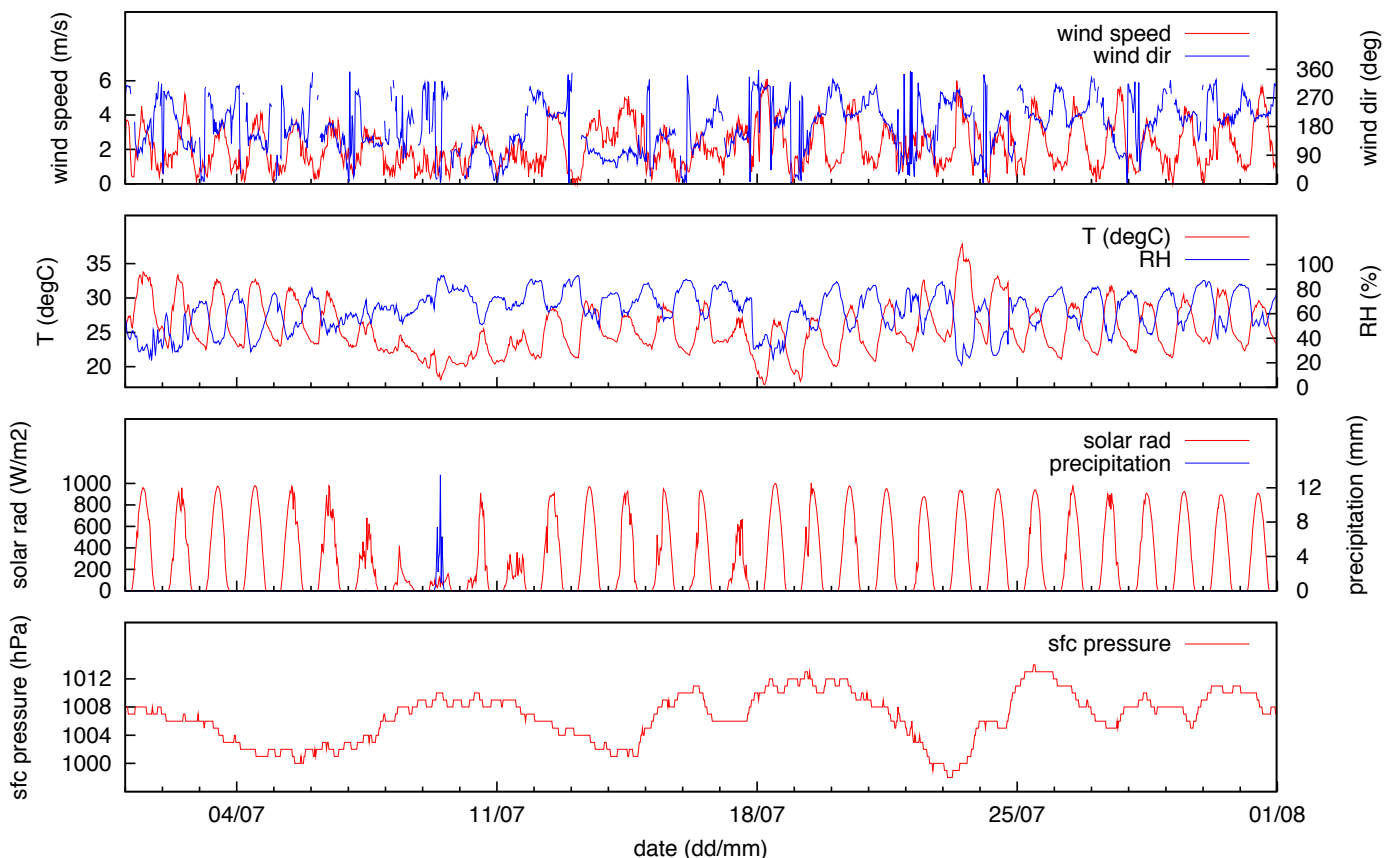

Fig. 12. Meteogram of $B C N$ site for the DAURE summer campaign (wind direction is plotted when wind speed is higher than $0.5 \mathrm{~m} \mathrm{~s}^{-1}$; measurements every $30 \mathrm{~min}$ ).

DAURE campaign meteorological overview

O. Jorba et al.

Title Page

Abstract

Introduction

Conclusions

References

Tables

Figures

14

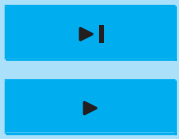

Back

Close

Full Screen / Esc

Printer-friendly Version

Interactive Discussion

(c) (i) 


\section{ACPD}

11, 4953-5001, 2011

Meteorological Station Montseny - CSIC
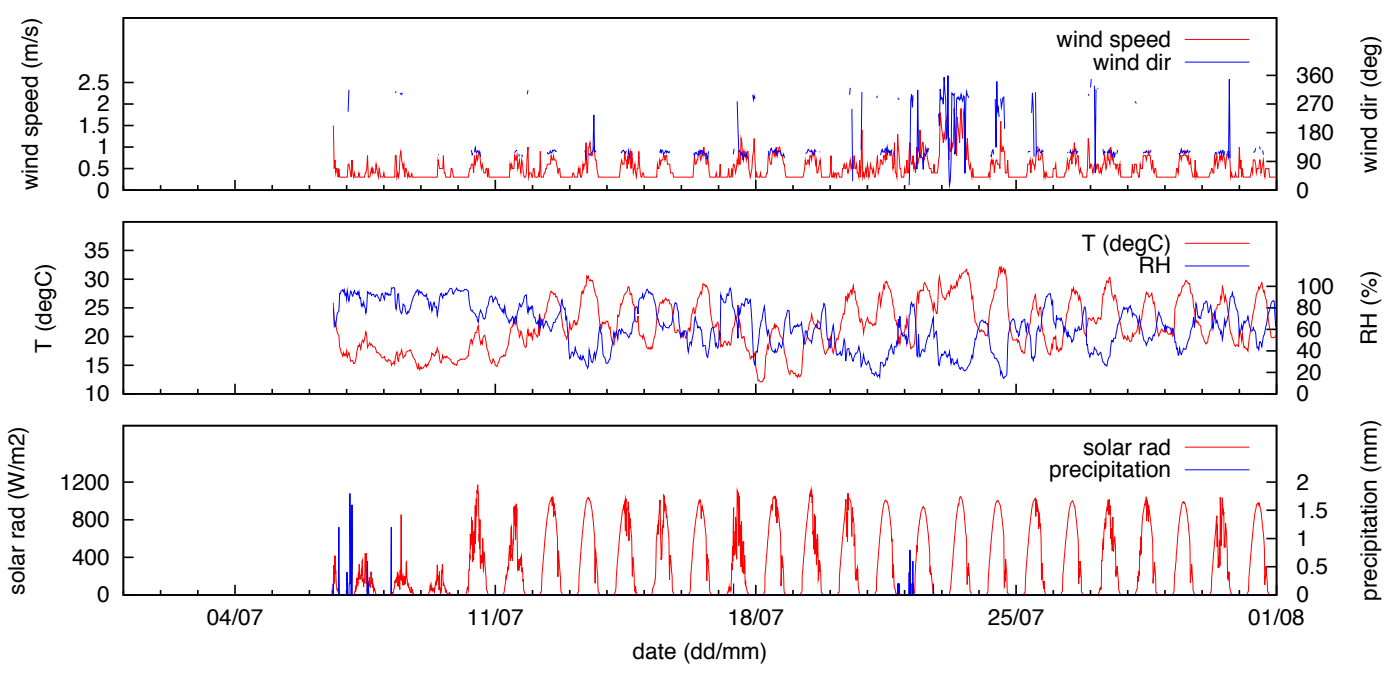

Fig. 13. Meteogram of MSY site for the DAURE summer campaign (wind direction is plotted when wind speed is higher than $0.5 \mathrm{~m} \mathrm{~s}^{-1}$; measurements every $10 \mathrm{~min}$ ).
DAURE campaign meteorological overview

O. Jorba et al.

Title Page

Abstract

Introduction

Conclusions

References

Tables

Figures

14

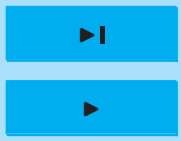

Back

Close

\section{Full Screen / Esc}

Printer-friendly Version

Interactive Discussion 


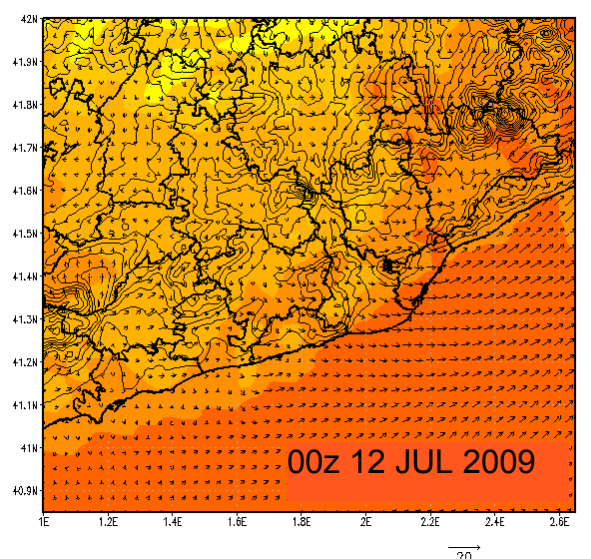

(a)

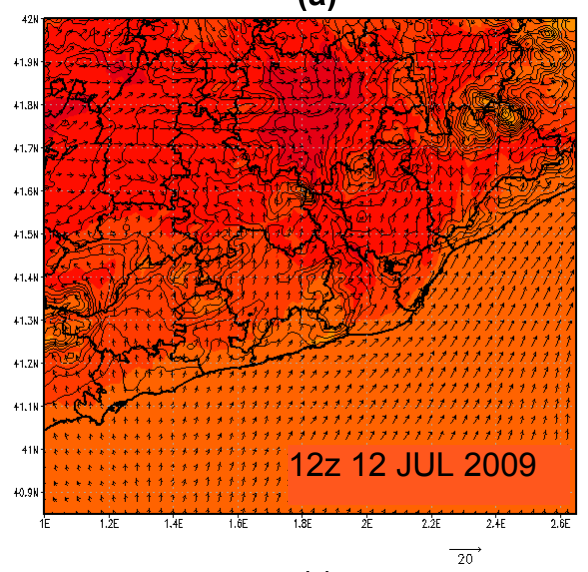

(c)

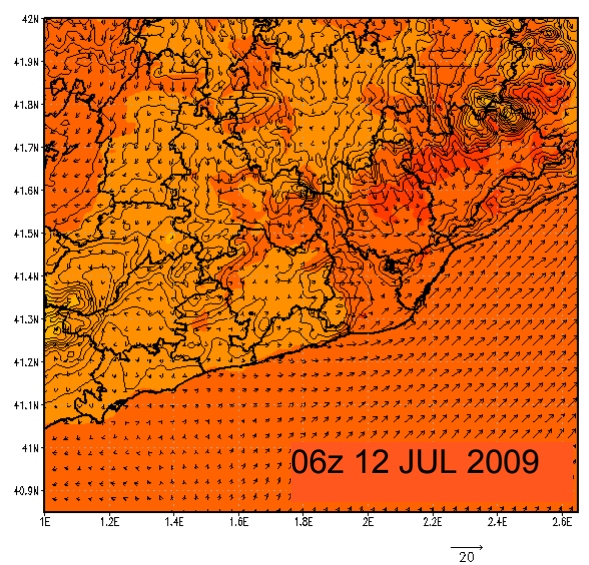

(b)

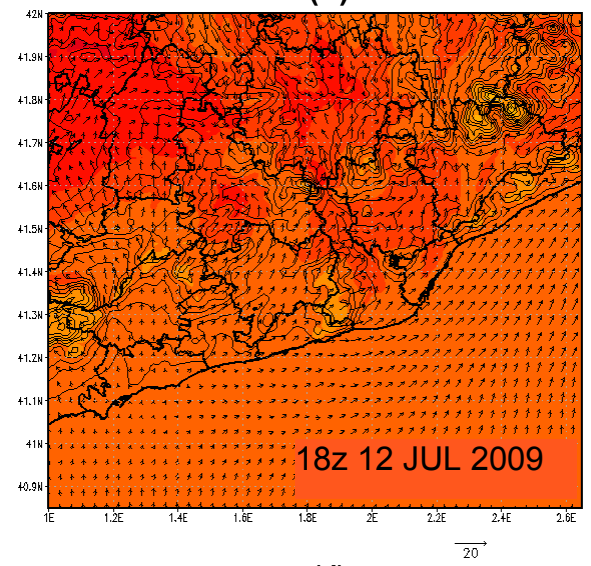

(d)

\section{ACPD}

11, 4953-5001, 2011

DAURE campaign meteorological overview

O. Jorba et al.

Title Page

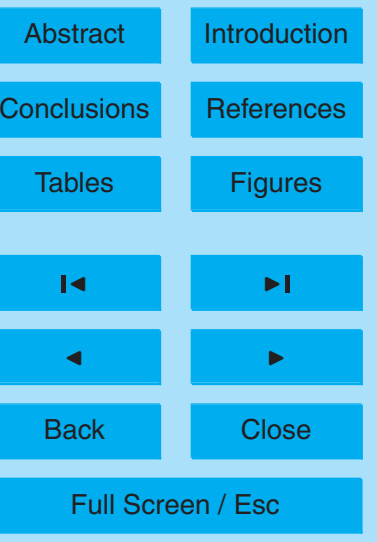

Printer-friendly Version

Interactive Discussion

Fig. 14. Surface wind field and temperature evolution for 12 July 2009 at (a) 00:00 UTC, (b) 06:00 UTC, (c) 12:00 UTC and (d) 18:00 UTC. 


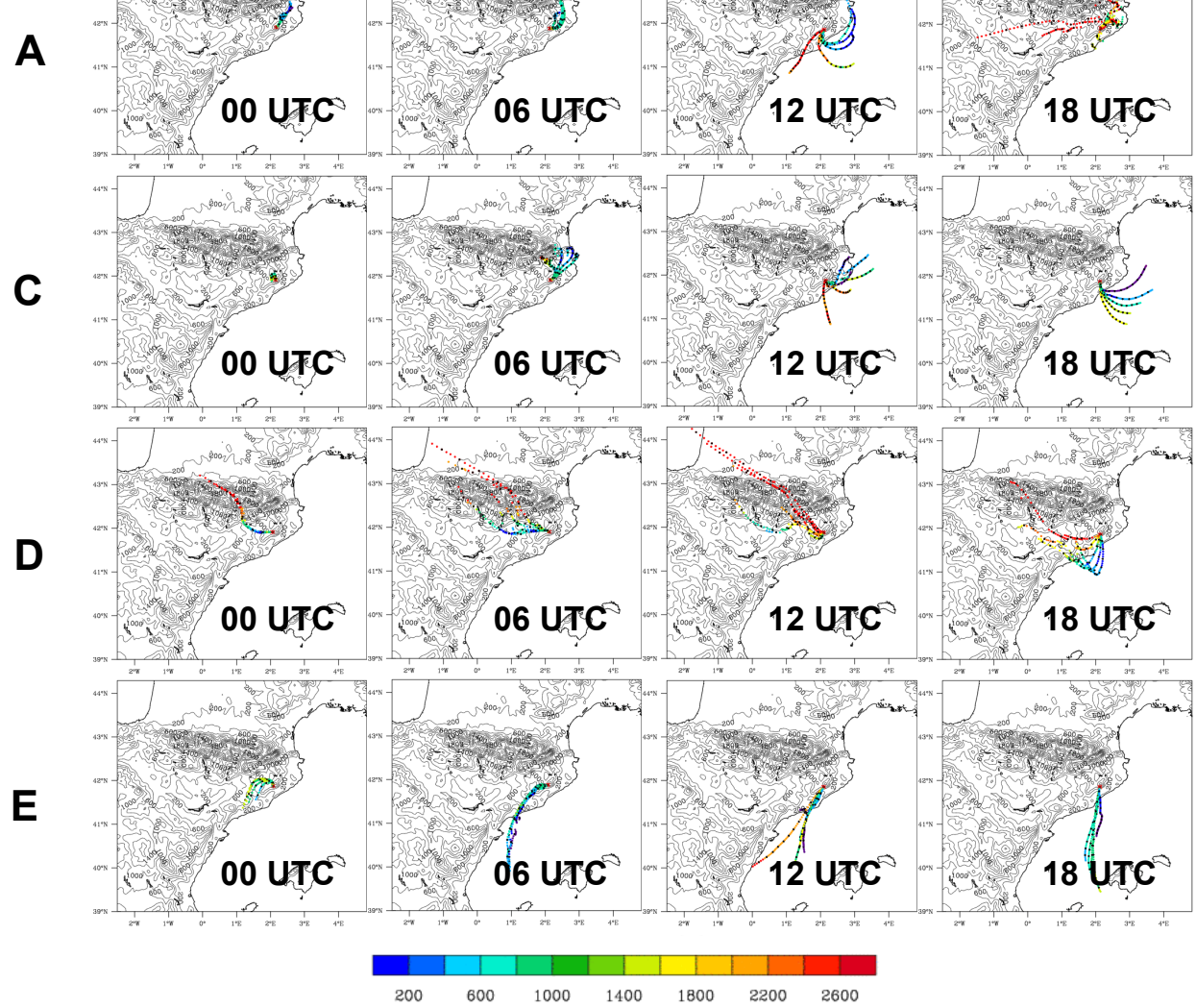

Fig. 15. Cluster-backtrajectories for typical situations of summer campaign. Trajectories are colored according to the altitude of the air mass in m a.g.l. (black points every hour). A: 5 July 2009 thermally driven land-see flows; C: 16 July 2009 eastern see-breeze regime; D: 18 July 2009 westerly advection; E: 21 July 2009 soutwestern advection.

\section{ACPD}

11, 4953-5001, 2011

DAURE campaign meteorological overview

O. Jorba et al.

Title Page

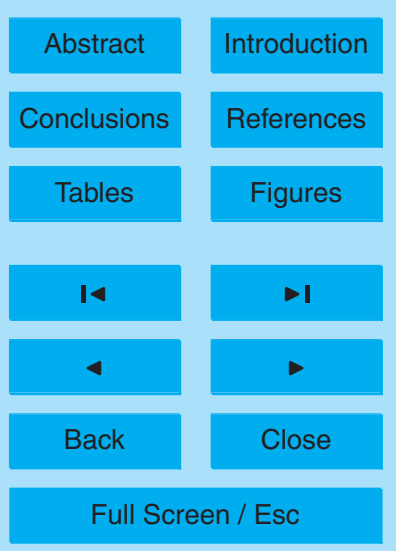

Printer-friendly Version

Interactive Discussion 